\title{
SAINS SEBAGAI KESELAMATAN DALAM PANDANGAN FRANCIS BACON
}

\author{
Karlina Supelli*
}

\begin{abstract}
Abstrak: Sains sebagai keselamatan adalah ungkapan yang kerap digunakan secara peyoratif untuk menggambarkan dampak sains dan teknologi yang mencelakakan manusia. Artikel ini akan menunjukkan bahwa ide "sains sebagai keselamatan" dapat dilacak ke Francis Bacon (1561-1626) dan ditafsirkan secara ketat menurut doktrin keselamatan Kristiani. Bacon merancang suatu program raksasa untuk meningkatkan proses pembelajaran dan pembaharuan pengetahuan. Namun, pada abad ke-16, setiap upaya untuk mencanangkan perluasan pengetahuan perlu terlebih dulu merehabilitasi status moral pengetahuan yang diasosiasikan dengan petaka di Firdaus, yang membawa dosa masuk ke dunia. Secara cermat Bacon menangani keprihatinan moral dan teologis zamannya dengan cara menjalin unsur eskatologis ke dalam programnya. Dia lalu menyuguhkan restorasi pengetahuan sebagai kasus partikular dalam sejarah keselamatan yang akan memulihkan penguasaan dan kuasa manusia atas alam, dan pada waktunya membebaskan manusia dari kesengsaraan material.
\end{abstract}

Kata-kata Kunci: Sains, alam, kejatuhan, pemulihan, instauratio, apokalips, sejarah keselamatan, kemaslahatan.

Abstract: 'Science as salvation' is a term used pejoratively to refer to the harmful impact of science and technology. This article will show that the idea of 'science as salvation' can be traced back to Francis Bacon (15611626) and was strictly construed according to the Christian doctrine of salvation. Bacon devised a comprehensive programme for the advancement of learning and the restoration of knowledge. But any sixteenthcentury proposals for the expansion of knowledge first required a

* Karlina Supelli, Program Pascasarjana Sekolah Tinggi Filsafat Driyarkara, Jl. Cempaka Putih Indah 100A, Rawasari, Jakarta 10520 adalah dosen di STF Driyarkara. E-mail: karlina.supelli@gmail.com 
rehabilitation of the moral status of knowledge long tainted by an image of catastrophe leading to the fall from the Garden of Eden, in which knowledge brought sins into the world. Bacon meticulously worked on the moral and theological concern of knowledge by weaving an eschatological element into his programme. He then espoused the restoration of knowledge as a particular case in the history of salvation envisaged to eventually restore human Arcadian mastery and dominion over nature, which in turn was expected to relieve humans from material sufferings.

Keywords: Knowledge, sin, fall, salvation, instauratio, apocalyps, sacred history.

\section{PENDAHULUAN}

Keselamatan adalah kata yang berkonotasi baik. Dalam Kamus Besar Bahasa Indonesia keselamatan berarti "perihal (keadaan) selamat; kesejahteraan; kebahagiaan dsb." ${ }^{1}$ Dalam tautan dengan teologi Kristiani, keselamatan secara khusus berarti "pembebasan dari dosa dan semua akibatnya" ${ }^{2}$ serta keadaan selamat dan damai sejahtera yang dianugerahkan oleh Allah kepada manusia (Lukas 2:29-32). Menjadi suatu ironi ketika artikel di laman terhubung Ensiklopedia Holocaust menggunakan ungkapan 'Science as Salvation' (sains sebagai keselamatan) untuk menggambarkan konsep pemurnian ras yang diwujudkan secara keji sepanjang perang dunia kedua oleh Nazi. ${ }^{3}$

Dengan ironi serupa, filsuf Inggris Mary Midgley memakai ungkapan itu bagi judul seri kuliah Gifford (1989-1990) di Universitas Edinburgh, Skotlandia. Dalam kuliah itu, Midgley menggambarkan sains sebagai mitos baru dalam masyarakat modern yang menggantikan peran

1 Kamus Besar Bahasa Indonesia, edisi ke-3 (Jakarta: Badan Pengembangan dan Pembinaan Bahasa, 2005).

2 Henk ten Napel, Kamus Teologi Inggris Indonesia (Jakarta: BPK Gunung Mulia, 2005).

3 Holocaust Encyclopedia, http://www.ushmm.org/wlc/en/article.php?ModuleId= 10007062

4 Mary Midgley, Science as Salvation: A modern Myth and its Meaning (London: Routledge, 1992). 
agama. ${ }^{4}$ Ironi itu menjadi tragedi ketika Dan Fagin menerbitkan laporan berjudul Toms River: A Story of Science and Salvation (2013) tentang ulah pabrik kimia. Alih-alih menyelamatkan orang dari sakit, pabrik obatobatan di kawasan New Jersey, Amerika Serikat, diam-diam membuang limbahnya ke sungai dan meningkatkan prevalensi kanker anak-anak dengan sangat mencolok.

Gambaran di atas bertolak belakang dengan gagasan tentang sains pada tahap awal perkembangannya, khususnya sepanjang peralihan dari Renaisans ke periode Modern. Tulisan ini akan memperlihatkan bahwa konsep "sains sebagai keselamatan" muncul pertama kali dalam pemikiran filsuf-cum-politisi Inggris Francis Bacon (1561-1626). Bacon tidak pernah memakai ungkapan itu. Namun, secara sistematik ia merancang jalan untuk menunjukkan bahwa sains dan penerapannya (artes mechanicx: ilmu rekayasa/teknik) merupakan bagian dari rencana keselamatan yang dijanjikan oleh Allah kepada manusia. Dengan langkah itu Bacon memelopori pengertian scientia operativa, yakni sains sebagai upaya untuk menemukan serta menerapkan pengetahuan dan bukan semata-mata kegiatan merenungkan alam demi mencapai kebenaran.

Bacon menuangkan pemikirannya ke dalam karya berjudul Instauratio magna (Restorasi Akbar, 1620)..$^{5}$ Instauratio adalah proyek ambisius untuk membangun filsafat alam baru yang akan menggantikan filsafat klasik dan abad pertengahan. Tujuannya adalah menyediakan metode yang tepat agar manusia dapat mendirikan kerajaan manusia di muka Bumi dengan mendayagunakan alam. Persoalannya, Bacon hidup pada zaman reformasi agama di Inggris yang ditandai dengan perpecahan, kekacauan dan kekejaman politik. Pertentangan Gereja Anglikan dengan

5 Saya menerjemahkan Instauratio menjadi restorasi, tetapi diperlukan penjelasan tambahan karena nanti akan terlihat bahwa Bacon memaknai 'instauratio' bukan semata-mata sebagai pembangunan kembali atau pembaharuan, tetapi mendirikan dari permulaan, dengan landasan yang baru, untuk kembali ke keadaan yang pernah ada sebelumnya. Restorasi di sini berarti demikian. 
kaum Protestan Puritan dan Katolik, serta pertikaian di kalangan pejabat istana dan parlemen memakan banyak korban. ${ }^{6}$

Pesimisme terhadap dunia meluas, khususnya di kalangan Puritan yang kecewa karena Ratu Elizabeth I (1533-1603) dan penggantinya, Raja James I (1566-1625), menolak reformasi total. Ketakutan akan datangnya akhir zaman begitu mencekam dan dilukiskan oleh filsuf terkemuka Thomas Hobbes (1588-1679) dengan menunjuk ke dirinya sendiri, "desas-desus beredar di semua kota bahwa hari penghabisan bagi negeri ini akan datang bersama serbuan armada. Ibuku begitu ketakutan sampai-sampai dia melahirkan bayi kembar, aku dan ketakutanku."7

6 Reformasi agama di Inggris tidak dapat dipahami hanya berdasarkan sejarah reformasi agama di Eropa Daratan. Sistem teologi yang dominan di Inggris semasa Bacon hidup adalah Teologi Reformasi yang berpegang ke otoritas Jean Calvin. Calvinis di Inggris terbagi atas kelompok Reformed nonkonformis yang disebut Puritan, tetapi sebetulnya menyebut diri the godly (kaum yang saleh). Sebutan Calvinis digunakan bagi kelompok Reformed konformis yang terbuka terhadap sistem teologi dan ritual Gereja Inggris yang masih mencantumkan ritual Gereja Katolik. Selama pemerintahan Elizabeth I, terjadi ketegangan antara teolog Gereja Inggris (Anglikan; dengan catatan sebutan Anglikan baru digunakan awal abad ke17) dan teolog Reformed nonkonformis yang ingin menegakkan reformasi total agar murni sesuai dengan ajaran Calvin dalam tata kebaktian dan tata gereja. Selain itu, ada perlawanan dari minoritas Katolik serta kelompok anti-Calvinis lainnya. Untuk mencegah perpecahan, Elizabeth I mengeluarkan ketetapan (Elizabethan Settlement 1559) yang tidak membatasi Gereja Inggris pada satu pola ibadah. Teologi Anglikan ditandai dengan sintesis dari berbagai penafsiran Kristiani. Bernard Verkamp menunjukkan pentingnya konsep adiaphora untuk memahami Gereja Inggris abad ke-16. Konsep ini menunjuk ke sikap lepas bebas (indifferent) dalam menafsirkan Keselamatan sehingga Gereja Inggris cukup bebas dalam mengembangkan doktrin dan moral Kristiani untuk membangun sistem teologi yang diharapkan akan melahirkan kestabilan politik. Landasan bagi adiaphora adalah pemisahan antara rahmat Allah dan tanggapan manusia, antara dogma (doktrin hakiki) dan pendapat saleh [disarikan dari Anthony Milton, Catholic and Reformed: The Roman and Protestant Churches in English Protestant Thought, 1600-1640 (Cambridge: University of Cambridge, 1995) dan Bernard J. Verkamp, The Indifferent Mean: Adiaphorism in the English Reformation to 1554 (Athens, OH: Ohio University Press, 1977)].

7 Aloysius P. Martinich, Hobbes: A Biography (Cambridge: Cambridge University Press, 1999), p. 2. 'Armada' dalam kalimat itu menunjuk ke ancaman armada perang Spanyol yang akhirnya dikalahkan oleh armada Inggris (1588). 
Dari sisi teologi, itulah zaman ketika kecurigaan terhadap pengetahuan sebagai penyebab dosa juga mengental. Dari sisi epistemologi, skeptisisme renaisans yang lahir bersama pembacaan kembali argumen Pyrrho (360-270 SM), Sextus Empiricus (160-210 M), Cicero (106-43 SM) dan Diogenes Laërtius ( \pm abad ke-3 M) merembes ke Inggris dan memasuki perdebatan di kalangan intelektual universitas Cambridge dan Oxford, serta terserap pula oleh sastra. Bacon mengerti, di atas lanskap politik dengan iklim teologi dan filsafat seperti itu, Instauratio bukan gagasan yang mudah diterima. Salah-salah malah dapat membahayakan kariernya sebagai pejabat tinggi istana.

Tulisan ini akan memperlihatkan beberapa persiapan Bacon untuk mewujudkan Instauratio bukan semata-mata sebagai corpus yang terbit tahun 1620, tetapi menjelmakannya sebagai peristiwa zaman. Ada tiga langkah persiapan. Pertama, Bacon menempatkan restorasi pengetahuan sebagai kelanjutan dari reformasi agama. Kedua, dia mengaitkan kemajuan sains dengan nubuat para nabi dan menunjuk beberapa peristiwa sejarah sebagai tanda penggenapannya sesuai Sejarah Keselamatan. ${ }^{8}$ Ketiga, mendahului itu semua Bacon merumuskan syahadat atau pengakuan iman (credo) yang memungkinkan dia merancang proyeknya dalam bingkai keselamatan Kristiani. Tulisan ini secara umum tersusun menurut tiga tesis tersebut, didahului dengan pembahasan tentang pemahaman Bacon akan situasi epistemik zamannya.

\section{MANUSIA JATUH KE DALAM DOSA}

Sepasang leluhur pertama manusia, Adam dan Hawa, sesudah diciptakan berdiam di Taman Firdaus. Mereka dalam keadaan kudus dan hidup selaras dengan alam. Mereka bertugas merawat taman itu dan boleh memakan semua buah, kecuali buah pohon pengetahuan tentang

8 Ada langkah keempat yang tidak kalah penting, yaitu persiapan landasan politik dan kebudayaan untuk mendukung kegiatan komunitas keilmuan secara terlembaga di bawah perlindungan raja. Langkah itu tidak saya bahas dalam tulisan ini. Sebagai informasi, Bacon mengembangkan cetak birunya dalam fiksi utopis New Atlantis (1627). 
yang baik dan yang jahat. Seekor ular datang dan membujuk Hawa dengan janji menggiurkan. Jika ia memakan buah terlarang itu, ia akan menjadi seperti Allah. Hawa ganti membujuk Adam. Mereka lalu memakan buah itu, yang berarti melanggar perintah Allah.

Untuk mencegah mereka juga memakan buah pohon kehidupan dan menjadikan mereka kekal, Allah menghalau mereka dari Firdaus. Pupuslah segala kenyamanan, kedamaian dan ketersediaan segala sesuatu. Itulah asal muasal perjuangan manusia untuk bertahan hidup yang penuh dengan kesengsaraan, dan masuknya maut ke dalam sejarah manusia. Sejak itu manusia mengenal dosa dan dosa pun membanjiri seluruh dunia. Keturunannya berbuat jahat dan saling membunuh. $^{9}$

Dalam Alkitab kemudian digambarkan rencana Allah dan tindakanNya bagi penyelamatan, dimulai dengan janji Allah kepada Abraham. Sejarah keselamatan berkembang sepanjang sejarah iman sampai ke nubuat para nabi tentang tujuan akhir Allah dan kedatangan penebus serta zaman yang lebih baik.

\section{KECURIGAAN TERHADAP PENGETAHUAN}

Apa hubungan narasi Kejatuhan dengan Instauratio magna? Untuk mendapat jawaban, kita perlu membaca keluh kesah Bacon lima belas tahun sebelumnya. Bacon menyayangkan kecenderungan banyak teolog yang mengaitkan pengetahuan dengan dosa. Bacon mengambil beberapa contoh seperti dikutip di bawah ini, ${ }^{10}$

9 Kisah Adam dan Hawa serta kejatuhan ke dalam dosa (selanjutnya: Kejatuhan) dikenal dalam semua agama Samawi dengan rincian berbeda-beda. Kisah di atas mengacu ke Kitab Kejadian dalam Alkitab (Lembaga Alkitab Indonesia, 2004).

10 Dalam tulisan ini, digunakan karya Bacon edisi Victoria yang tersusun dari dua seri: Seri (1) karya filosofis dan profesional: Francis Bacon, The Works of Francis Bacon, edited by James Spedding, Robert Leslie Ellis and Douglas Denon Heath, in 7 volumes (London: Longman, Green, Longman and Roberts, 1859-64). Rujukan ditulis sebagai berikut: Judul, Volume: halaman + aphorisme (jika ada). Angka Romawi menunjuk ke Book I, Book II, dan seterusnya. Contoh: Novum organum Book I, Vol 4: 91 disingkat 
Kudengar para teolog bilang pengetahuan mesti diwaspadai dan diterima dengan pembatasan. Bahwa hasrat berlebihan akan pengetahuan merupakan sumber godaan dan dosa yang menyebabkan kejatuhan manusia. Bahwa pengetahuan mengandung ular dan akan membuat orang bergembung dada kalau sampai terkena-Scientia inflat [pengetahuan menjadikan orang sombong]. Bahwa Salomo pernah mengecam, menulis buku tak akan ada akhirnya, dan banyak membaca membuat badan letih, dan di bagian lain, di dalam banyak pengetahuan ada banyak kesusahan, siapa memperbanyak pengetahuan, memperbanyak kesedihan. Bahwa St. Paulus memberi peringatan, jangan kita terpikat filsafat yang kosong. ${ }^{11}$

Bacon tidak menyebut siapa "para teolog" itu. Mengingat pada abad ke-16 sebagian besar sebagian besar teolog berasal dari kelompok Puritan, catatan itu kiranya dimaksudkan untuk, antara lain, menyebut William Perkins (1558-1602), Henry Smith (1560-1901), Thomas Wright (15351601) dan John Downame (1571-1652). Bacon sendiri dibesarkan dalam

Novum I, 4: 91. Jika merujuk ke editornya, seri ini disingkat SEH. Seri (2) surat-surat: Francis Bacon, The Letters and the Life of Francis Bacon, edited by James Spedding, in 7 volumes (London: Longman, Green, Longman and Roberts, 1861-74); ditulis Letters, Vol.: hlm. Untuk naskah yang baru ditemukan pada abad ke-20 digunakan Francis Bacon, The Oxford Francis Bacon, general editor Graham Rees, in 15 volumes (Oxford: Clarendon Press, 1996-...), versi Oxford Scholarly Editions Online (OSEO) dan disingkat OFB. Karena belum semua volume edisi OFB terbit, edisi Victoria masih berfungsi sebagai pustaka baku dalam kajian tentang Bacon.

11 The Advancement and Proficiency of Learning I, 3:264. Bacon tidak pernah mencantumkan rujukan ke Alkitab. Namun, kalimat cetak miring (oleh Bacon) mengacu secara berurutan ke 1 Korintus 8:1, Pengkhotbah 12:12, 1:18 dan Kolose 2:8. Bacon kadangkadang memparikatakan petikannya, seperti Pkh. 1:18 di atas. Dalam Geneva Bible tertulis, "For in multitude of wisdome is muche grief: $\mathcal{E}$ he that encreaseth knowledge, encreaseth sorrow." Bacon menulis "That in spatious knowledge, there is much contristation, and that he that encreaseth knowledge, encreaseth anxietie." Semasa Bacon hidup lazim digunakan Geneva Bible (1560), Bishop's Bible (1568), Vulgata dan King James Bible (KJV) $1^{\text {st }}$ edition (1611). Dalam menelusuri dan membandingkan, saya mengacu ke Geneva Bible untuk tulisan Bacon sebelum KJV terbit, berdasarkan informasi dari Brian Vickers mengenai penyebutan Salomon dalam tulisan Bacon (Brian Vickers (ed.), Francis Bacon: The Major Works. Oxford World's Classics (Oxford: Oxford University Press, 2008), p. xl). Untuk terjemahan, kecuali disebut berbeda, saya mengacu ke Alkitab (Lembaga Alkitab Indonesia, 2004) dan saya sesuaikan jika ada modifikasi dari Bacon. Untuk versi Latin (Vulgata dan Junius -Tremellius) lihat Daftar Pustaka. 
keluarga Puritan. Ibunya, Lady Ann Cooke Bacon, adalah perempuan Puritan sangat terpelajar dan dikenal baik di kalangan teolog Puritan.

Dari kajian Peter Harrison tentang hubungan antara paham dosa asal dan kecurigaan terhadap pengetahuan, para teolog di atas tergolong giat menyebarluaskan paham bahwa pengetahuan pada hakikatnya berbahaya bagi moral. Mereka mengaitkan pengetahuan dengan kesombongan-dosa di urutan paling atas dari tujuh dosa terbesar manusia dalam tradisi Kristiani. Perkins, yang reputasinya di Universitas Cambridge waktu itu hampir-hampir tidak tersaingi, menghubungkan keingintahuan intelektual dengan Kejatuhan yang mengakibatkan seluruh ciptaan tercemar oleh dosa asal. Perkins juga mengaitkan kegelisahan intelektual dengan praktik magi dan sihir. Jika tanpa batas, hasrat akan pengetahuan mendorong orang memanfaatkan segala cara untuk membongkar rahasia alam yang berada di luar jangkauannya. ${ }^{12}$

Kecurigaan itu tidak dapat dilepaskan dari ajaran Calvin tentang kerusakan total (total depravity), yaitu bahwa seluruh diri manusia sudah tercemar secara negatif oleh dosa. Dosa asal merusak semua aspek diri manusia termasuk akalbudi, tubuh, perasaan, nurani, dan kehendaknya sehingga manusia sama sekali tidak mampu melakukan kebajikan sejati yang dikehendaki Allah. ${ }^{13}$ Ajaran Gereja Katolik yang memahami keselamatan sebagai hasil kerja sama antara rahmat Allah dan perbuatan baik manusia ditolak, demikian pula paham kebebasan manusia sesudah Kejatuhan. Di Inggris khususnya, ajaran tentang kehancuran radikal kodrat manusia akibat dosa asal, meminjam kajian William M. Spellman, "menempati posisi sangat penting dan aktif dalam kehidupan kerohanian

12 Peter Harrison, "Curiosity, Forbidden Knowledge, and the Reformation of Natural Philosophy in Early Modern England," Isis, Vol. 92 (2001), pp. 265-290; bdk. Harrison, "Original Sin and the Problem of Knowledge in Early Modern Europe," Journal of the History of Ideas, Vol. 63, No. 2 (Apr., 2002), pp. 239-259; bdk. Perez Zagorin, Francis Bacon (Princeton: Princeton University Press, 1998), pp. 47-48.

13 Lih. Anthony A. Hoekema, Manusia: Ciptaan menurut Gambar Allah, diterjemahkan oleh Irwan Tjulianto, disunting oleh Hendry Ongkowidjojo (Surabaya: Penerbit Momentum, 2012)]. 
Gereja dan komunitas intelektual secara keseluruhan." ${ }^{14}$ Terlepas dari perbedaan di antara teolog Puritan dan Anglikan waktu itu, mereka umumnya berpegang ke penafsiran tersebut. ${ }^{15}$

Dari sisi filsafat, skeptisisme renaisans melahirkan permasalahan epistemologi dengan variasi yang rumit dan belum selesai terpetakan seluruhnya sampai hari ini. Sekurang-kurangnya dapat dikatakan bahwa Bacon berhadapan dengan rembesan skeptisisme Eropa Daratan yang variasinya terentang mulai dari taktik anti-rasionalis Agrippa dari Nettesheim (1486-1535) yang menghancurkan semua bidang pengetahuan manusia karena tidak berguna dan berbahaya, sampai diktum quod nihil scitur (tak ada yang dapat diketahui) Francisco Sanchez (15521623) tentang sifat mentak pengetahuan. ${ }^{16}$

Pengaruh variasi itu terlihat misalnya pada John Donne (1532-1631), sastrawan sekaligus pendeta terkemuka yang acap menyindir optimisme Bacon terhadap sains. Sementara Bacon memandang zamannya sebagai masa peralihan menuju zaman keemasan pengetahuan, dengan pesimisme yang mendalam Donne menamainya "zaman besi yang sudah berkarat."17 Majas yang dipergunakan oleh Lancelot Andrewes (15551626), Uskup Winchester yang ikut mempersiapkan King James Bible,

14 Spellman, Locke and the Problem of Depravity (Oxford: Oxford University Press, 1988), pp.8-9. Bdk. Harrison, The Fall of Man and the Foundations of Modern Science (Cambridge: Cambridge University Press, 2007).

15 Calvin mengembangkan antropologi teologis Agustinus yang intinya mengatakan bahwa Kejatuhan membawa manusia memasuki keadaan tidak mampu untuk tidak berdosa dan mati (non posse non pecarre et mori) [Jeff B. Pool, God's Wounds: Hermeneutic of the Christian Symbol of the Divine Suffering, Vol. 2 (Eugene: Wipf \& Stock, 2010), p. 174].

16 Disarikan dari Gianni Paganini and José R. Maia Neto (eds.), Renaissance Scepticisms (Dordrecht: Springer, 2009).

17 Pesimisme Donne terhadap metode eksperimental yang diusulkan oleh Bacon terbaca dari petikan berikut, "bunga bulan Juli tidak dapat kita bangunkan di bulan Januari, tidak pula kita dapat menunda bunga musim semi hingga musim gugur...Segala sesuatu ada akadnya... Alam tidak mau dipacu dan tidak mau dipaksa untuk menyesuaikan derapnya...segala sesuatu ada waktunya" (John Donne, Meditation XIX, http:/ /www.luminarium.org/sevenlit/donne/meditation19.htm). 
kiranya dapat menggambarkan cuaca intelektual sepanjang Reformasi di Inggris, "pengetahuan iman ibarat cahaya fajar yang kian cemerlang, pengetahuan nalar laksana malam yang kian kelam."18

\section{RESTORASI SEBAGAI KELANJUTAN REFORMASI}

Antropologi yang menekankan Kejatuhan serta konsekuensi epistemiknya yang muram itu, bagi Bacon, merupakan hambatan terbesar bagi sains. Pada usia 26 tahun, dia sudah menyampaikan kepada pamannya bahwa cita-cita kontemplatifnya sangat luas kalau dibandingkan dengan keinginan praktisnya menangani urusan publik. "Sebab, sudah kuputuskan bahwa semua bidang pengetahuan adalah wilayahku."19

Dari surat itu saja sudah kelihatan bahwa Bacon tidak terpengaruh oleh pesimisme zaman. Dia menganggap bahwa tugasnya yang paling berat adalah "menanamkan kembali pengharapan" terhadap pengetahuan. ${ }^{20}$ Secara konkret, pengharapan itu dia lekatkan ke metode induksi yang dia sebut sebagai "perangkat baru" (novum organum) untuk menjalankan sains. Dia sungguh yakin, jika metode itu itu diikuti "tidak bisa tidak" perbaikan atas kondisi manusia akan "datang dengan sendirinya." ${ }^{21}$

Dalam risalah-risalahnya kita menemukan pelbagai upaya Bacon untuk meyakinkan pembaca bahwa pengetahuan bukan penyebab Kejatuhan. Sebaliknya. Allah telah "menganugerahkan dunia ke dalam hati" manusia. Segala sesuatu yang merupakan bagian dunia telah "Dia sesuaikan dengan pemahaman manusia," asalkan manusia membuka akalbudi seluas-luasnya tetapi tidak mencoba-coba untuk membongkar

18 Dikutip dalam Steven Matthews, Theology and Science in the Thought of Francis Bacon (Hampshire: Ashgate Publishing Limited, 2008). p. 77.

19 Surat kepada Lord Burghley 17 Agustus 1587 (Letters, 1: 109).

20 Novum I, 4: 90-91, Aph. XCII.

21 Novum II, 4:247, Aph. LII. Novum organum adalah judul risalah bagian kedua Instauratio yang dimaksudkan untuk menggusur logika Aristoteles dalam Organon. 
rahasia Allah. ${ }^{22}$ Pemilahan antara rahasia Allah dan pengetahuan manusia ini penting untuk memahami bagaimana Bacon menafsirkan Kejatuhan dan akan dibahas di bagian lain tulisan ini.

Bacon menggunakan metafora "Dua Kitab" untuk menunjuk Alkitab (kitab pertama) dan "segenap ciptaan" (kitab kedua). Alkitab menyampaikan "kehendak Allah," sedangkan alam dan segala isinya "menyatakan kekuasaan-Nya." Untuk menekankan betapa penting mempelajari kedua kitab itu dan tidak memilih secara berat sebelah, Bacon menaruh kutipan, "Kamu sesat, sebab kamu tidak mengerti Kitab Suci maupun kuasa Allah." ${ }^{23}$

Keseimbangan itulah yang menurut Bacon belum terjadi. Dia tidak menemukan zaman ketika para cerdik cendekia memberi cukup perhatian bagi penyelidikan alam yang akan membawa perbaikan bagi hidup sehari-hari manusia. Padahal ada periode ideal di mana benih sains semestinya dapat tumbuh dengan subur. ${ }^{24}$ Penilaian negatif ini perlu kita lihat dari sudut pandang Bacon yang membagi filsafat alam menjadi penyelidikan teoretis (spekulatif) untuk memahami penyebab dan kegiatan rekayasa untuk memproduksi akibatnya (operatif). Filsafat alam bukan semata-mata melakukan pencarian ke dalam perut bumi, melainkan perlu juga menempa alam agar memberi manfaatnya kepada manusia..$^{25}$

22 Valerius terminus: Of the Interpretation of Nature, 3:221; Novum I, 4: 91, Aph. XCII. Cetak miring oleh Bacon, mengacu ke Pengkhotbah 3:11. Bacon menggunakan 'dunia' (dan bukan 'kekekalan' seperti dalam terjemahan LAI). Diskusi tentang kata yang tepat (dunia, kekekalan, atau ketidaktahuan) cukup ketat (Tremper Longman, The Book of Ecclesiastes, New International Commentary on the Old Testament (Grand Rapids: Eerdmans, 1998), II.C 1), tetapi tidak penad (relevan) di sini karena Bacon sudah membuat pembatasan antara pengetahuan manusia dan pengetahuan Allah.

23 Valerius, 3:221; Advancement I, 3:300-301. Bdk. Matius 22:29.

24 Bacon membuat semacam penyigian atas sejarah filsafat dan mengaku hanya menemukan kurang dari enam abad bagi periode ideal tersebut. Dalam rentang enam abad itu ada tiga periode yang dia anggap menonjol (Yunani, Romawi dan zamannya sendiri).

25 De Dignitate augmentis scientiarum, IV, 4: 346. 
Sepanjang periode ideal zaman filsafat Prasokratik, dia menilai perhatian utama "Ketujuh Orang Bijak terkecuali Thales," ${ }^{26}$ lebih tercurah ke filsafat moral dan politik. Terlebih-lebih "sesudah Sokrates menurunkan filsafat dari langit ke bumi, filsafat moral semakin populer dan menjauhkan orang dari filsafat alam." Pada periode Romawi situasinya tidak berbeda, "benak yang paling istimewa dibaktikan bagi urusan publik." ${ }^{27}$ Memasuki zamannya sendiri, Bacon masih menggerutu seperti terlihat di bawah ini,

Sekarang, ketika iman Kristiani telah diterima dan kian mapan, pemikirpemikir terbaik mengabdikan diri bagi teologi. Bayaran di bidang itu memang paling besar dan segala jenis pelayanan tersedia secara berlimpah. Teologi mengambil porsi terbesar periode ketiga ini...dan menjadi-jadi dengan datangnya Renaisans. Apalagi kemudian pecah konflik agama...Walhasil, filsafat alam menjadi lorong saja bagi orang yang numpang lewat atau sekadar jembatan untuk mencapai hal lainnya. ${ }^{28}$

Penyigiannya yang bersifat historis dan epistemis terhadap sejarah pemikiran, baik berupa analisis kritis maupun preskriptif, sangat panjang. ${ }^{29}$

26 Sebutan bagi Thales dari Miletus, Solon dari Athena, Kilon dari Sparta, Bias dari Priene, Kleobulos dari Lindos, Pittakos dari Mytilene, dan Periandros dari Mison (menurut Diogenes Laërtius, Lives of the Eminent Philosophers, Vol. I in two volumes, trans. Robert Drew Hicks (Cambridge, MA: Harvard University Press, 1959), I.13 Prologue.

27 Novum I, 4: 72, 77-78, Aph. LXXI, LXXVIII. Kritik Bacon tidak mengada-ada dan dapat kita bandingkan dengan data tentang minat terhadap sains sepanjang abad ke-16 dan 17 di Inggris yang dihimpun oleh Robert Merton. Kesimpulan Merton, sains paling-paling dikerjakan sebagai kesenangan saat senggang [Robert K. Merton, “ Science, Technology and Society in Seventeenth Century England," Osiris, Vol. 4 (1938), p. 385].

28 Novum I 4: 78-79, Aph. LXXIX-LXXX.

29 Pergulatan intelektual Bacon melawan tradisi pembelajaran klasik, skolastik dan humanistik yang dia nilai menghambat perkembangan sains tertuang dalam Advancement. Dalam 'Rencana Kerja' Instauratio magna, Bacon menjelaskan bahwa Book II Advancement (1605) dan perluasannya De dignitate et augmentis scientiarum (1623) merupakan persiapan untuk memasuki Instauratio (Instauratio, 4: 22). Secara harafiah itu berarti pembaca perlu membaca Advancement untuk mengerti alasan Bacon mencanangkan restorasi pengetahuan. Secara kiasan, usulannya bagi perbaikan 
Kita terpaksa melompat ke era yang membuat Bacon akhirnya dapat bersyukur karena keadaan mulai berubah. Jasa atas perubahan itu ia sandangkan ke pundak Martin Luther. Jika diringkas, Bacon mengatakan bahwa Luther, dalam rangka perlawanannya terhadap "Bishop of Rome dan tradisi gereja yang merosot" dan di tengah-tengah kesendiriannya tetapi “dibimbing oleh Penyelenggaraan agung," tidak menemukan topangan dalam sistem teologi zamannya. Luther pun mempelajari naskah awal Gereja dan ternyata "menegakkan kembali zaman lampau." Luther "memanggil masa lalu agar mengulurkan pertolongannya untuk melawan masa kini. Demikianlah para penulis kuno, baik di bidang teologi maupun kemanusiaan, yang lama tertidur di perpustakaan mulai dibaca dan beredar lagi," tulis Bacon. ${ }^{30}$

Kita perlu agak hati-hati membaca bagian ini. Bacon betul bahwa reformasi Protestan erat berkaitan dengan bangkitnya minat untuk mempelajari kembali naskah klasik Yunani dan Romawi yang belum dikomentari oleh sarjana abad pertengahan. Meski demikian, mengatakan bahwa minat itu muncul sebab ada reformasi Protestan adalah dakuan yang terlalu besar, dan terlebih-lebih, salah urutan. Minat itu sudah muncul di Italia kurang lebih seabad sebelum Reformasi, baik sebagai gerakan intelektual sekular maupun agamawi. Ketika menyebar ke Eropa Utara, minat itu terpusat pada pada teologi dan slogan Renaisans, ad fontes (kembali ke sumber asli), dimaknai sebagai kembali ke dokumen Patristik serta Alkitab berbahasa Ibrani dan Yunani. Humanisme renaisans Eropa Utara ini adalah salah satu pembuka jalan bagi Reformasi. Mengutip Alister McGrath, Reformasi adalah "akibat tidak terelakkan dari perkembangan gerakan di Italia abad ke-14 yang sekarang kita kenal dengan sebutan Renaisans Italia."31

kurikulum—jika diwujudkan—akan membuka jalan untuk menyambut Instrauratio sebagai peristiwa sejarah.

30 Advancement I, 3: 282-283.

31 Alister McGrath, Reformation Thought: An Introduction (Oxford: Willey-Blackwell, 2012), p. 35. 
Sedikit ganjil kalau penjelasan Bacon yang keliru disebabkan oleh kurangnya informasi. Boleh jadi, dia sengaja menegaskan bahwa Luther berjasa tidak saja dalam membangun "agama yang sehat," tetapi juga "nalar yang tepat." Kelak dalam Instauratio Bacon menyatakan kedua hal itu merupakan prasyarat supaya manusia dapat mendayagunakan "haknya atas alam sesuai karunia ilahi." 32 Akan tetapi, jika penjelasan terbalik itu kita kaitkan dengan reaksi Gereja Katolik terhadap Reformasi Protestan, Bacon tidak terlalu keliru seperti terlihat dari kalimat berikut,

Kita saksikan dengan mata kepala kita sendiri bahwa sekarang ini dan sepanjang zaman bapak-bapak [Gereja Protestan] kita, manakala Allah berkenan menegur Gereja Roma agar mempertanggungjawabkan kemerosotan perilaku dan ritual-ritualnya...pada waktu yang tepat bersamaan-melalui Penyelenggaraan Ilahi—ditetapkan bahwa pembaharuan dan pemunculan aneka ragam pengetahuan mesti berjalan juga. Dan di sisi lain kita saksikan para Yesuit...berhasil mempercepat dan memperkuat situasi pembelajaran...betapa nyata pelayanan dan perbaikan yang telah mereka lakukan bagi Tahta Suci. ${ }^{33}$

Bagian pertama kutipan itu cukup jelas mengacu ke reformasi Protestan. Sedangkan bagian kedua ("pada waktu...") perlu dimengerti dalam konteks Kontrareformasi ketika Gereja Katolik melaksanakan pembaharuan menyeluruh dalam kehidupan Gereja, dimulai dengan Konsili Trento (1545-1563). Sesi ke-23 Konsili (15 Juli 1563) mengeluarkan beberapa ketetapan, salah satunya mengenai tata laksana pendidikan calon imam melalui sekolah khusus yang disebut seminari ("wadah persemaian"). ${ }^{34}$

Dalam bidang inilah Bacon melihat peran para Yesuit (anggota ordo religius Serikat Yesus) berhasil melaksanakan reformasi pendidikan, mempercepat pelaksanaannya sekaligus meningkatkan mutu penge-

32 Novum I, 4: 115, Aph. CXXIX.

33 Advancement I, 3: 300.

34 J. Waterworth (trans. \& ed.), The Council of Trent: The canons and decrees of the sacred and oecumenical Council of Trent (London: Dolman, 1848), Ch. XVIII, pp. 187-188. https:// history.hanover.edu/texts/trent/ct23.html. 
tahuan..$^{35}$ Bacon begitu terkesan, sampai-sampai dia mengibaratkan dirinya Agesilaus, Raja Sparta yang dengan berat hati mengakui kelebihan musuhnya, Pharnabazus, "talis quum sis, utinam noster esses [mereka begitu bagus, kuharap mereka ada di pihak kita]." ${ }^{36}$ Dia melihat Kontrareformasi sebagai berkah terselubung yang ikut menggerakkan Restorasi.

Kalau kita simak, Bacon menggunakan dua cara untuk mengaitkan Reformasi dengan Restorasi. Mula-mula dia membubuhkan penanda waktu untuk menjalin keduanya ke dalam satu peristiwa dan kemudian menegaskan adanya penyelenggaraan ilahi yang menggulirkan Restorasi, sebagaimana sudah lebih dulu terjadi pada Reformasi. Selanjutnya, Bacon memerlukan dukungan alkitabiah. Penalarannya demikian: jika betul Reformasi dan Restorasi terjadi bersamaan bukan karena kebetulan atau kausalitas alami belaka, tentu dia akan menemu-kan petunjuknya dalam sejarah Sejarah Keselamatan. Bacon menyebut "Sacred History" yakni rekaman atas tindakan imanen Allah di dunia. ${ }^{37}$

35 Kegiatan pendidikan dan karya intelektual para Yesuit menjadi salah satu gerakan yang paling kokoh dalam Kontrareformasi. Pada masa Bacon menulis karyakaryanya, sudah berdiri sekitar 300-an kolese Yesuit di Europa, Asia, dan Amerika Latin untuk siswa dari semua golongan, calon imam dan awam, dengan variasi usia antara 12 dan 20 tahun. Kurikulum kolese menangani hal-hal yang persis merupakan keprihatinan Bacon. Kolese Yesuit berperan besar dalam menyebarluaskan pemikiran baru dalam filsafat alam (teori Copernicus, Kepler, Galileo, dan lain-lain). Banyak Yesuit merupakan matematikawan, filsuf alam, dan astronom terkemuka [John Patrick Donnelly (trans. \& ed.), Jesuit's Writings of the Early Modern Period, 1540-1640 (Indianapolis: Hackett Publishing, 2006), p.15. Bdk. Mordechai Feingold and Victor Navarro-Brotons, Universities and Science in the Early Modern Period (Dordrecht: Springer, 2006)].

36 Advancement I, 3: 277, 300. Pujian ini sangat mencolok mengingat Yesuit termasuk pihak yang bersikeras mengembalikan Gereja Inggris ke bawah otoritas Paus. Beberapa pemberontakan melawan Reformasi di Inggris dicurigai sebagai plot mereka. Salah satunya adalah upaya mendudukkan Mary Ratu Skotlandia yang beragama Katolik di tahta kerajaan, mengganti Elizabeth I. Mereka juga dituduh sebagai otak di belakang rencana pembunuhan James I (Gunpowder Plot, 1605), kendati tidak terbukti. Kecurigaan ini menjelaskan pujian yang disampaikan dengan 'berat hati'.

37 Sacred History (di atas diterjemahkan: Sejarah Keselamatan) digambarkan sebagai berikut, "Karena sejarah penyelenggaraan ilahi melampaui sejarah manusia, narasi 


\section{PENGGENAPAN NUBUAT DANIEL}

Bacon hidup dalam kurun penjelajahan bangsa Eropa ke seluruh dunia yang diikuti dengan perluasaan kekuasaan politik dan ekonomi melalui penetapan kolonisasi. Para penjelajah dan saudagar berkeliling dunia dan membawa pulang aneka ragam wujud hayati serta nonhayati yang sangat asing bagi orang Eropa. Semua itu mendorong keinginan untuk mengoleksi dan menyelidiki lebih jauh macam-macam benda asing. Namun, banyak di antara temuan itu tidak lagi dapat dimengerti dengan filsafat alam yang ada. Bacon juga terpesona oleh benda seperti kompas, kartografi, mesin cetak, dan mesiu yang semuanya mempunyai kegunaan langsung. Semua itu penting bagi Bacon bukan hanya dari segi ilmu, melainkan juga untuk menyusun argumen tentang tanda-tanda zaman yang dapat membangkitkan kepercayaan bahwa sains layak dan pantas dikejar. Bagaimana dia melakukan itu, marilah kita simak ilustrasi sampul-dalam Instauratio magna (gambar 1).

Dua pilar raksasa tegak bagai gerbang bagi kapal yang datang dan pergi. Satu kapal mendekat dan satu lagi menjauh ke tengah samudera. Bagi pembaca zaman Renaisans, pilar-pilar itu akan mengingatkannya pada tiang-tiang Hercules. Tiang-tiang khayal itu diasosiasian dengan Selat Gibraltar yang sejak dahulu kala diyakini sebagai batas jelajah terjauh manusia. Karena gelombangnya ganas, para pelaut percaya tidak ada orang yang sanggup mengarungi dan apalagi menyelidiki kawasan itu. Platon menyampaikan mitos itu dalam Timaeus (25c-d) dan

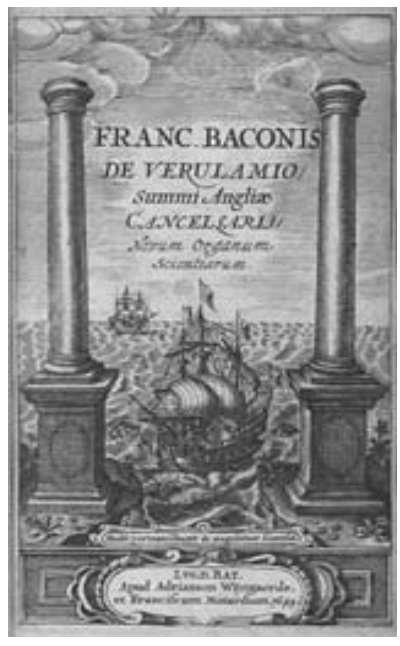

Gambar 1. Instauratio magna ${ }^{38}$

Sejarah Keselamatan dapat berupa kisah sesudah ataupun sebelum kejadian (berupa nubuat)" (Dignitate I, 4: 293).

38 Edisi 1645. Sumber: EC.B1328.620ib, Houghton Library, Harvard University. Bebas hak cipta. 
Critias (116b-c). Dari cara kedua kapal mengisi bidang gambar tersebut pesan Bacon terbaca dengan tegas: Mitos itu sudah gugur. ${ }^{39}$

Meski demikian, ilustrasi itu bukan sekadar perayaan atas keberhasilan eksplorasi geografis menembus "batas dunia." Makna yang jauh lebih luas terdapat dalam kalimat yang tertera di fondasi, "multi pertransibunt \& augebitur scientia" (banyak orang akan melintas \& pengetahuan akan bertambah). Kalimat ringkas itu adalah modifikasi atas nubuat Daniel (12: 4). ${ }^{40}$ Mengingat kutipan ini muncul beberapa kali, Bacon tentu menganggapnya penting. Alasannya kita temukan dalam Valerius, tempat kutipan itu muncul pertama kali,

Ini adalah perihal yang aku sendiri tidak tahu, apakah mungkin aku mengatakannya dengan gamblang sebagaimana terpikir. Yaitu, bahwa semua pengetahuan seumpama pohon yang ditanam sendiri oleh Allah. Oleh sebab itu, penyebaran dan perkembangannya pun, atau paling tidak buah-buahnya, tampaknya ditetapkan bagi musim tuai dunia sekarang ini melalui penyelenggaraan ilahi-bukan hanya penyelenggaraan umum, melainkan juga pewahyuan khusus. Karena menurut hematku tidaklah akan melecehkan dan lagi pula sekarang peristiwanya sudah berlangsung, cukup aman jika aku menafsirkannya sesuai nubuat Daniel ketika dia membicarakan akhir zaman dan berkata, banyak orang akan melintas hilir mudik, dan sains akan bertambah. Seolah-

39 Secara tekstual pesan itu dia sampaikan dalam Advancement II: 321-322.

40 Entah sengaja atau tidak, Bacon mencampur Daniel 12:4 versi Vulgata (Katolik), plurimi pertransibunt, et multiplex erit scientia dengan versi Tremellius \& Junius (Protestan), percurrent multi \& augebitur cognitio. Hasilnya adalah multi pertransibunt $\mathcal{E}$ augebitur scientia (garis bawah adalah penekanan saya). Kutipan ini muncul dalam versi berbeda-beda. Dalam Redargutio Philosophiarum, tertulis multi pertransibunt et multiplex erit scientia (7: 93). Dalam Advancement (II, 3: 340), Bacon mengutip utuh versi Vulgata dalam Latin. Ayat ini juga dikutip dalam Novum I, 4: 92 dan Valerius, 3: 221. Dalam Valerius, kutipan tertera dalam bahasa Inggris, "many shall pass to and fro, and science shall be increased" (banyak orang akan melintas hilir mudik, dan sains akan bertambah). Bdk. KJV, "many shall run to and fro, and knowledge shall be increased". Saya menerjemahkan tanpa mengacu ke LAI karena kata "menyelidiki" tidak menangkap dua maksud Bacon, yaitu (1) keberhasilan pelaut bulak balik melintasi Selat Gibraltar, dan (2) hubungan antara keberhasilan itu dan bertambahnya pengetahuan (Untuk rujukan Alkitab Latin yang digunakan lihat Daftar Pustaka). 
olah, terbukanya dunia oleh pelayaran dan perdagangan serta penemuan pengetahuan selanjutnya sudah semestinya bertemu di kurun atau zaman yang sama. ${ }^{41}$

Dalam petikan di atas, dengan susah payah Bacon berusaha menunjukkan tanda-tanda lahiriah yang mengindikasikan bahwa peristiwa yang dinubuatkan itu mulai tergenapi. Kendati Bacon menggunakan kata "ditetapkan," "penyelenggaraan ilahi" dan "sudah semestinya," sebagai pemikir yang merumuskan metode ilmu empiris, tampak ia cukup berhati-hati dalam mengaitkan fakta duniawi dengan fakta iman. Apalagi, penalarannya memakai pola retrospektif: sesudah memeriksa fakta, dia merasa aman (safe now after the event) untuk menelusuri sejarah tindakan ilahi dan menemukan kesejajaran dalam pernyataan eskatologis Daniel. $^{42}$

Dalam penelitian ilmu sosial kontemporer pendekatan retrospektif diterima sebagai langkah sahih sejauh dijalankan dengan cermat. Meski demikian, penjelasan post factum mengandung risiko. Bacon kelihatan seperti mengotak-atik peristiwa untuk memberi makna kepada fakta, supaya fakta itu mengemuka sebagai kasus khusus dari suatu faktor yang lebih umum. Sederhananya, mencocokkan fakta dengan kabar terselubung yang pernah mengemuka. Tidak jarang hasilnya adalah penjelasan semu.

Bacon bukannya tidak menyadari risiko itu. Ketika membahas subjek kajian teologi, khususnya Sejarah Eskatologi, dia menuntut keahlian khusus bagi para penafsir sastra apokalips karena tindakan Allah tidak begitu saja dapat dibaca menggunakan penalaran manusia. ${ }^{43} \mathrm{Di}$ tempat lain, kesulitan itu dia lukiskan dengan mengutip Lukas 17:20 tentang cara kerja Allah yang tidak kentara sehingga orang tidak menge-

41 Valerius, 3: 220-221.

42 Bdk. Matthews, Theology and Science, 90.

43 Dignitate II, 4: 312-313. Bacon memakai perumpamaan dalam 2 Petrus 3: 8, “Di hadapan Tuhan satu hari sama seperti seribu tahun dan seribu tahun sama seperti satu hari." 
nalinya. ${ }^{44}$ Penggunaan kata "tampaknya" (appeareth) serta "seolah-olah" (as if) dalam kutipan di atas adalah cara Bacon untuk menunjukkan bahwa dia melontarkan dugaan, dan bukan dakuan.

Kitab Daniel berisi penglihatan profetik Nabi Daniel ketika malaikat Mikhael menyingkap rencana Allah mengenai apa yang akan terjadi pada akhir zaman, diikuti dengan datangnya Kerajaan Allah di dunia. Dengan menaruh sejarah duniawi ke atas panggung penyelenggaraan ilahi, Bacon membawa pengharapan profetik ke kawasan kemungkinan real di mana sains berperan sebagai jalan keselamatan material.

Dari sini kita menemukan dua makna Instauratio yang saling berkelindan, yaitu Instauratio sebagai pemikiran Bacon dan Instauratio sebagai peristiwa zaman ketika cahaya "nalar yang tepat" menyingsing bersama-sama dengan "agama yang sehat." Instauratio yang tertuang ke dalam karya cetak (1620) merupakan persiapan metodologis untuk melanjutkan Instauratio buah karya Allah. Bacon berniat menunjukkan bahwa reformasi agama dan restorasi pengetahuan sama-sama merupakan penggenapan sebagian dari peristiwa eskatologis yang akan datang, yaitu lahirnya dunia lebih baik yang dijanjikan oleh Allah. Sementara reformasi agama di Inggris sudah mencapai bentuk idealnya, ${ }^{45}$ restorasi pengetahuan mulai bergulir.

Kendati pada mulanya merayap pelan sebagai peristiwa kecil yang tak tersadari, Instauratio yang "pada mulanya berasal dari Allah...sudah barang tentu akan sampai ke tujuan akhir." Dia yakin restorasi penge-

44 Novum I, 4: 91, Aph. XCIII. Lukas 17:20, “Kerajaan Allah datang tanpa tanda-tanda lahiriah."

45 Bacon memuji ketetapan Elizabeth I dan James I yang bahkan lebih toleran lagi terhadap keragaman penafsiran teologis. Dia juga mengungkap jasa James dalam penyusunan Alkitab King James Version (Advancement II, 3:488). Bacon tentu tidak membahas kepentingan politik James I yang tidak mau dimakzulkan dan oleh karena itu, mencoba mendapat dukungan dari semua pihak, baik Protestan konformis, nonkonformis maupun Katolik. Lihat Robert G. Clouse, "John Napier and Apocalyptic Thought," The Sixteenth Century Journal, Vol. 5, No. 1 (Apr., 1974), pp. 101-114 
tahuan berasal dari Allah karena corak baik yang diperlihatkan dalam peningkatan pengetahuan. Tugas Bacon adalah melanjutkan guliran itu dan dimulai dengan memperbaiki cara orang berpikir serta membangun pengharapan. ${ }^{46}$

Semakin jelas bahwa ilustrasi dua kapal itu juga berfungsi sebagai kiasan bagi penjelajahan memasuki "kerajaan manusia (regno hominis)" yang dibangun di atas sains. Bacon sendiri menyebut karyanya sebagai "sebuah apokalips atau visi yang benar tentang jejak Pencipta yang terpateri pada ciptaan." ${ }^{47}$ Corak apokaliptik ${ }^{48}$ pemikiran Bacon terlihat dari pilihan kata instauratio yang muncul pertama kali sebagai judul fragmen pendek "Temporis partus masculus, sive instauratio magna imperii humani in universum" (Kelahiran Maskulin Waktu, atau Restorasi Akbar Kuasa Manusia di Dunia). ${ }^{49}$

46 Novum I, 4: 91-92, Aph. XCIII. Argumen ini kelanjutan dari aforisme sebelumnya di mana Bacon menjelaskan langkah konkret untuk "membangkitkan harapan," yaitu menyiapkan pangkalan data empiris berupa tabel bermacam-macam gejala alam dan penjelasannya.

47 Instauratio, 4: 33.

48 Apokaliptisisme, apokaliptik atau apokalipsis berasal dari kata Yunani apokalyptein atau apokaly too yang berarti menyingkapkan atau mewahyukan informasi tersembunyi menyangkut kejadian terkait manusia. Dalam Injil, kata "apokalipsis" muncul dalam Kitab Wahyu Yohanes 1:1, "Inilah wahyu Yesus Kristus" (apokalypsis Iesu Khristou). Eskatologi berasal dari kata Yunani eskhatos (akhir) dan merupakan ajaran yang menunjuk ke segala peristiwa yang akan datang, baik dalam kaitan dengan apa yang akan dialami oleh individu ataupun dunia secara keseluruhan. Secara umum, visi pokok pengharapan apokaliptik diartikan sebagai pengharapan akan terjadinya suatu peristiwa monumental yang akan mengubah eksistensi manusia dan terbukanya tabir Kerajaan Allah. Pengharapan ini dapat disertai dengan, atau tanpa antisipasi akan akhir zaman. Akhir zaman dimaknai sebagai berakhirnya kuasa kejahatan dan datangnya Kerajaan Allah yang mencakup langit dan bumi yang diperbarui (Yesaya 65:17; 66:22) [Paul Hanson, "What is Apocalyitic Literature," in John J. Collins (ed.), The Oxford Handbook of Apocalyptic Literature, (Oxford: Oxford University Press, 2014), pp. 1-16].

49 Diterjemahkan oleh Benjamin Farrington menjadi The Masculine Birth of Time or the Great Instauration of the Dominion of Man over the Universe [Benjamin Farrington, The Philosophy of Francis Bacon: An Essay on its Development from 
Charles Whitney, yang menelusuri kata "instauratio" dalam karya Bacon sejak tahun 1603, yakin bahwa Bacon menyadari makna alkitabiah kata itu. Bacon menyebut Tuhan sebagai "Instaurator" dan pada saat bersamaan Bacon menyebut proyeknya "universum opus instaurationis (karya semesta tentang pembaharuan)." ${ }^{50}$ Seperti dijelaskan Whitney, sumber Kristiani kata itu adalah adalah Vulgata. Instauro digunakan untuk menunjuk ke restorasi Bait Suci yang didirikan oleh Salomo ( \pm abad ke-10 SM), setelah dihancurkan oleh tentara Babel (586 SM). Kata itu juga dipakai secara simbolik oleh Agustinus bagi sejarah penebusan, yaitu tegaknya Perjanjian Baru. ${ }^{51}$

Dengan menguatnya apokaliptisisme di Inggris, ${ }^{52}$ makna alkitabiah kata itu tentu tidak asing. Apalagi ketika masih bergelar James VI Raja Skotlandia, James menggambarkan dirinya sebagai raja bijak nan pandai, Sang Salomo dari Skotland. Ketika dinobatkan sebagai James I menggantikan Elizabeth I, Inggris pun dibayangkan akan menjadi Jerusalem Baru. ${ }^{53}$ Terlepas dari itu semua, seperti sempat dikatakan oleh Whitney, mungkin saja Bacon sekadar meniru judul buku Tycho Brahe

1603 to 1609 with New Translations of Fundamental Text (Liverpool: Liverpool University Press, 1964), pp. 60-72].

50 Charles Whitney, "Francis Bacon's Instauratio: Dominion of, and over, Humanity," Journal of the History of Ideas, Vol. 50 No. 3 (July - September 1989), pp. 380, 377-378. Bdk. Bacon, Historia naturalis et experimentalis ad condendam philosophiam (Natural and Experimental History for the Foundation of Philosophy 2: 15-16 (Latin). Spedding menerjemahkan "Instaurator" menjadi "Renewer" (Experimental, 5: 134).

51 Whitney, “Bacon's Instauratio," pp. 377-378, 380. Kata itu ada di Mazmur 104:29 dan Efesus 1:10.

52 Tentang gejala apokaliptisisme di Inggris, lihat Richard Bauckham, Tudor Apocalypse: Sixteenth Century Apocalypticism, Millenarianism and the English Reformation: From John Bale to John Foxe and Thomas Brightman (Oxford: The Sutton Courtenay Press, 1978).

53 James Doelman, King James I and the Religious Culture of England (Cambridge: D.S. Brewer, 2000), p. 75. Catatan: bayangan Inggris sebagai Jerusalem Baru, yang mengacu ke Wahyu 2:12, secara sederhana dapat kita simak dari himne Inggris yang terkenal, "Jerusalem," gubahan Hubert Perry (1916) dengan lirik "And did those feet in ancient time"dari epik Milton (William Blake, 1804). Milton menuliskannya berdasarkan legenda tentang Yesus Kristus yang konon menapakkan kaki di tanah Inggris ketika masih kanak-kanak. 
(1546-1601), Astronomix instauratx progymnasmata (Latihan Pendahuluan bagi Pembaharuan Astronomi, 1602). ${ }^{54}$ Dari corak kekuasaan dan nafas apokaliptik yang dilekatkan oleh Bacon ke kata itu, juga seandainya ada pengaruh Tycho, paling jauh sebatas inspirasi bagi judul. Cukup pasti, Bacon memaknainya lebih daripada semata-mata pembaharuan.

Maka pertanyaan yang menggelitik adalah mengapa Bacon memakai kata yang konotasinya adalah mendirikan sesuatu untuk balik ke hal atau keadaan yang pernah ada? Padahal Bacon sendiri menganggap sains dan filsafat yang ada tidak bermanfaat karena tanpa kegunaan praktis. Dia juga mengatakan bahwa satu-satunya jalan untuk mendapatkan sains seperti yang dia cita-citakan adalah mendirikan dari permulaan sebuah landasan baru yang sepenuhnya berbeda, bagi semua bidang ilmu yang pernah dipelajari oleh manusia? ${ }^{55}$

\section{CARA ADAM MENAMAI DUNIA}

Dari anak judul risalah Temporis terlihat bahwa tujuan Bacon adalah menegakkan kembali kuasa manusia atas alam. Namun, belum jelas balik ke kekuasaan macam apa kata itu menunjuk. Kita menemukan jawabannya dalam perumusan Bacon tentang "tujuan sejati sains," yaitu "memulihkan dan mengembalikan kepada manusia kedaulatan dan kekuasaan yang pernah dimilikinya pada tahap awal penciptaan." Ke dalam kurung di belakang kalimat itu dia sisipkan kata-kata "sebab barang siapa dapat memanggil segenap ciptaan dengan nama sejatinya, ia akan menguasai mereka lagi." ${ }^{56}$ Kendati Bacon tidak menyebut sumber, pembaca berlatar agama samawi mungkin mengenali sebagian maknanya. Dalam Alkitab, mengacu ke Kejadian 2:19-20.

54 Whitney, "Bacon's Instauratio," p. 371. Sangat besar kemungkinan Bacon tahu ada buku itu karena Tycho mempersembahkan kepada James I ketika masih bergelar James VI.

55 Instauratio, 4:7-8.

56 Valerius, 3:222. 
Kegiatan Adam memberi nama dalam perumusan Bacon adalah "merangkum proses mengetahui" yang terdiri atas pengamatan dan penamaan. Pengamatan mewakili aksi dan penamaan mewakili kontemplasi. ${ }^{57}$ Terlihat bahwa bagi Bacon memberi nama kepada sesuatu tidak hanya merupakan tindakan linguistik, tetapi juga proses semantik menghubungkan kata dengan benda. Memanggil "dengan nama sejatinya" mengandaikan kemampuan untuk membedakan satu wujud dari wujud lainnya berdasarkan sifat, fungsi, rupa, dan sebagainya. Dalam Perjanjian Lama, kemampuan untuk memilih dan memilah itu terungkap saat Adam menamakan pasangannya. Sebelum Kejatuhan Adam memanggilnya "perempuan" karena mengacu ke asal usulnya, "Inilah dia, tulang dari tulangku dan daging dari dagingku" (Kejadian 2:23). Sesudah Kejatuhan, dia memanggil pasangannya "Hawa" sesuai dengan kodratnya, yaitu "menjadi ibu semua yang hidup" (Kejadian 3:20).

Diktum Bacon, "pengetahuan manusia menyatu dengan kekuasaannya" kiranya perlu dipahami dalam konteks Bacon menganalisis sumber kuasa Adam atas ciptaan, yaitu kemampuan mengetahui sifat atau hakikat wujud yang diberi nama. ${ }^{58}$ Adam mampu membangun relasi semantik antara benda (acuan) dan kata (makna), res et verba. Bagi Bacon kemampuan itu mencerminkan hubungan langsung yang ideal antara akalbudi dan alam semesta. Bacon menyebutnya sebagai pengetahuan murni tentang alam dan universalitas (pure knowledge of nature and universality), pengetahuan melalui terang akalbudi (knowledge by the light) atau terang murni pengetahuan kodrati (pure light of natural knowledge). ${ }^{59}$

57 Advancement I, 3:264-265, 296.

58 Simak aforisme III, "Pengetahuan manusia menyatu dengan kekuasaannya. Sebab, ketika penyebab tidak diketahui efeknya pun tidak dapat dimunculkan"(Novum I, 4:47, Aph. III). Ringkasan populer "pengetahuan adalah kekuasaan" tidak terlalu tepat menyampaikan pemikiran Bacon.

59 Advancement I, 3:264; Valerius, 3:219. Catatan: pengetahuan kodrati adalah pengetahuan yang diperoleh berdasarkan kemampuan manusia karena kodratnya (indera, akalbudi, intuisi). Sejak abad pertengahan, tingkat kemampuan akalbudi diibaratkan 
Pandangan tentang keistimewaan akalbudi Adam sebelum Kejatuhan lazim sampai sekarang. Para teolog abad ke-16 dan 17 umumnya percaya kemampuan itu disebabkan oleh akalbudi, indera dan hasrat saling bertaut sesuai dengan maksud awal ketika Adam diciptakan. ${ }^{60}$ Ada keyakinan bahwa pada mulanya akalbudi manusia dirancang untuk mengetahui kebenaran. Bagi Bacon, tautan itu menjamin perpaduan yang sempurna antara kontemplasi dan aksi, akalbudi dan alam, kata dan benda. Tautan itu putus oleh Kejatuhan. Bacon mengambil sosok Habel sang penggembala serta Kain si petani sebagai pengejawantahan paling purba dari tercerainya kontemplasi dan aksi dalam diri manusia. ${ }^{61}$ Gembala menjalani hidup yang kontemplatif karena mempunyai waktu senggang sambil menunggui ternaknya merumput. Tidak demikian halnya dengan si petani yang sepanjang hari membanting tulang mengolah tanah.

Bacon menunjuk peristiwa Babel sebagai penanda simbolik bagi kerusakan lebih lanjut hubungan tersebut. Itulah saat Allah membuat kacau bahasa semesta manusia dan menjadikan manusia tidak lagi saling mengerti bahasa di antara mereka. Perkembangan pengetahuan pun terhambat. Dia juga menyebut peristiwa Pentakosta-yang berlangsung ketika sejarah penebusan sudah berjalan melalui kematian dan kebangkitan Yesus Kristus—sebagai pembalikan dari peristiwa Babel. Dalam peristiwa itu Roh Kudus tercurah sehingga bangsa yang berbedabeda kembali saling mengerti bahasa yang diujarkan. Di bagian ini, Bacon tampaknya sengaja menekankan fungsi bahasa sebagai vehicula scientix (wahana pengetahuan). ${ }^{62}$

cahaya/terang sehingga dikatakan, misalnya, terang akalbudi Adam lebih cemerlang daripada terang akalbudi manusia biasa.

60 Peter Harrison, “Original Sin,” p. 242.

61 Advancement I, 3:297.

62 Advancement I, 3:297, 299. Peristiwa Babel: Kejadian 11:9; Peristiwa Pentakosta: Kisah 2:1-11. 
Alih-alih membaik, pembelajaran filsafat sepanjang sejarah membuat hubungan itu semakin problematis. ${ }^{63}$ Dunia "menjadi budak pikiran dan pikiran menjadi budak kata-kata...perdebatan orang terpelajar berujung di kontroversi tentang kata dan nama." ${ }^{64}$ Padahal bagi Bacon, relasi semantik yang tepat antara akalbudi dan alam merupakan perangkat yang paling mangkus untuk memahami kinerja alam. Sebagai jalan pemulihan, dia menawarkan metode induksi untuk menginterpretasikan alam. Metode induksi mengarahkan akalbudi kembali ke benda-benda sehingga orang sungguh memeriksa fakta, dan tidak sekadar menerkanerka atau bernujum lalu membangun dunia tiruan karangannya sendiri. ${ }^{65}$ Bacon melukiskan pemulihan hubungan antara "Akalbudi dan Dunia" secara figuratif sebagai "perkawinan sejati dan sah antara daya empiris dan rasional manusia." 66

\section{ALLAH YANG TERSEMBUNYI}

Dari paparan di atas, cukup kelihatan bahwa Bacon tidak berpegang ke doktrin kerusakan total. Konsep teologis di belakang Instauratio adalah Kejatuhan menghilangkan dua hal sekaligus dari manusia, kekudusan manusia dan kuasanya atas alam. ${ }^{67}$ Kuasa itu hilang karena alam memberontak kepada manusia, bukan karena akalbudinya rusak. Matthews menjadikan kalimat Bacon "pemahaman manusia menjadi bobrok oleh adat dan kebiasaan buruk" sebagai salah satu petunjuk bahwa Bacon menjauh dari Calvinisme. ${ }^{68}$

63 Selain usia manusia yang relatif pendek dan cara kerjanya yang keliru, metode pewarisan pengetahuan merupakan sumber hambatan perkembangan sains (Advancement I, 4: 265).

64 Kritik itu ditujukan ke "berhala pasar" (idola fori) dalam gejala bahasa yang terjadi karena manusia menambahkan ke dalam kata, makna yang belum tentu ada atau bahkan pasti tidak ada dalam realitas. Makna tanpa acuan itu karangan filsafat dan teologi belaka (Novum I, 4:61, Aph. LIX).

65 Experimental, 5:127.

66 Instauratio, 4:19, 27.

67 Novum II, 4: 248, Aph. LII.

68 Matthews, Theology and Science, p. 73. Bdk. Novum II, 4:168, Aph. XXVIII. Pertanyaan sejauh mana pendidikan Puritan mempengaruhi pemikiran Bacon muncul dalam 
Di atas sudah dikutip kritik Bacon kepada para teolog Puritan. Dalam pertimbangan Bacon, mereka semua kurang menyimak sehingga keliru menafsirkan ayat-ayat terkait. ${ }^{69}$ Manusia di Firdaus sudah memiliki pengetahuan tentang segenap ciptaan. Semua hewan tunduk kepadanya. Tidak ada yang perlu ditambahkan lagi kepada manusia, kecuali apa yang ada dalam bisikan iblis, "kamu akan menjadi seperti Allah." Lugasnya, godaan yang membuat manusia jatuh bukanlah pengetahuan pada umumnya, melainkan pengetahuan yang dapat membuat manusia memberontak terhadap Allah. Dalam kalimat Bacon sendiri, "manusia berhasrat menetapkan aturan bagi dirinya sendiri sehingga dia tidak lagi bergantung kepada hukum Allah." Hakikat godaan itu bukan hasrat pengetahuan, tetapi kesombongan dan ambisi manusia "untuk memasuki terlalu jauh rahasia Allah."70

Pernyataan terakhir sekaligus menunjuk ke batas pengetahuan manusia. Bacon merumuskan "rahasia Allah" sebagai pengetahuan di tataran pertama mengenai "prinsip semesta gerak atau Ringkasan Hukum Alam." Pengetahuan tentang hal ini selama-lamanya akan "tersembunyi di balik tirai-Nya." ${ }^{71}$ Di tempat lain dia menyebutnya sebagai naluri materi perdana atau prinsip pertama gerak dan keanekaragaman materi. Itulah prinsip asali yang ditetapkan oleh Allah bagi penataan alam semesta sejak penciptaan sampai akhir zaman, atau relasi sebabdan-akibat yang terdapat dalam setiap kejadian sejak awal sampai akhir

diskursus abad ke-20 tentang Bacon sesudah Charles Webster dan Christopher Hill menekankan Bacon sebagai leluhur intelektual di belakang Perang Saudara (16421651). Dalam perang yang berakhir dengan pelaksanaan hukuman mati bagi Charles I (1649), sebagian besar kekuatan oposisi adalah kaum Puritan. Baik Hill maupun Webster menggambarkan Bacon sebagai Calvinis yang saleh [Charles Webster, (New York: Holmes and Meier Publishers, 1976); Christopher Hill, Intellectual Origins of the English Revolution - Revisited (Oxford: Clarendon Press, 1997)].

69 Lih. "Kecurigaan terhadap Pengetahuan" dalam tulisan ini.

70 Advancement I, 3:264-265, 296; Instauratio, 4:20; Valerius, 3:217-218, 219. Bdk. Kejadian $3: 22$, "Sesungguhnya manusia telah menjadi seperti salah satu dari Kita, tahu tentang yang baik dan yang jahat."

71 Valerius, 3:220. 
yang ada dalam pikiran atau rencana Allah. ${ }^{72}$ Pengetahuan manusia terletak di tataran kedua kedua, yaitu mengani kecenderungan dalam benda serta relasi-relasinya yang menimbulkan aneka perubahan teramati di alam. ${ }^{73}$

Matthews menghubungkan konsepsi Bacon tentang batas pengetahuan manusia dengan konsep deus absconditus, yakni Allah yang tersembunyi melampaui akalbudi manusia. ${ }^{74}$ Ketika membahas "Dua Kitab," Bacon memang mengatakan bahwa sains dapat membantu manusia mengenali “jejak-jejak kekuasaan-Nya yang terpateri di dalam ciptaan." Akan tetapi, citra Allah dalam ciptaan sedemikian tidak lengkap dan tidak memadai sehingga tidak mungkin memberi pengetahuan tentang Allah. ${ }^{75}$ Tentang Allah, orang hanya bisa takjub, tulis Bacon. "Berikan kepada iman apa yang menjadi hak iman," demikian Bacon menegaskan. ${ }^{76}$

Petikan itu tidak jarang ditafsirkan sebagai pemilahan yang ketat antara sains (filsafat alam) dan teologi, sampai tidak lagi saling berinteraksi dan masing-masing jalan dalam kawasannya sendiri. ${ }^{77}$ Jika disimak, petikan itu diarahkan sebagai kritik terhadap refleksi filosofis yang berujung dengan melekatkan sosok ilahi ke wujud khayal yang

72 Valerius, 3:220; Of the Wisdom of the Ancient, 6:725, 729. Bdk. On the Principles and Origins according to the Fables of Cupid and Cœlum, etc., 5:463; Description of the Intellectual Globe 4: 349. Dalam Advancement (II, 3:356) pernyataannya lebih positif, "tentang prinsip [pertama] ... kita tidak tahu apakah akalbudi manusia dapat mencapainya atau tidak."

73 Valerius, 3:220.

74 Matthews, Theology and Science, pp. 95, 112-113.

75 Advancement I, 3: 300-301; Valerius, 3: 221.

76 Novum I, 4: 66, Aph. LXV; Advancement II, 3: 350; Matius 22:21.

77 Misalnya penafsiran John Gascoigne, "The Religious Thought of Francis Bacon," in Carole M. Cusack and Christopher Hartney (eds.), Religion and Retributive Logic. Essays in Honour of Professor Garry W. Trompf (Leiden: Brill, 2010), pp. 209 - 228; lih. Benjamin Milner, "Francis Bacon: the Theological Foundations of 'Valerius Terminus,'” Journal of the History of Ideas, Vol. 58, No. 2 (April 1997), pp. 245-264; lih. Markku Peltonen, The Cambridge Companion to Bacon (Cambridge: Cambridge University Press, 1996), khususnya Ch. I dan Ch. 7. 
dibangun dari konsep tanpa acuan yang tepat (apotheosis). Campur aduk seperti itulah yang dia hubungkan dengan "filsafat yang kosong" (kutipan Paulus di atas). ${ }^{78}$

\section{Masalah Takdir vs. Kebebasan Manusia}

Sampai di sini, upaya Bacon masih terlihat sebagai sekadar mencaricari dukungan alkitabiah supaya proyeknya tidak dituduh bidah. Belum terlihat konsep teologi yang cukup sistematik untuk mendukung dakuannya. Masalah inilah yang menimbulkan silang pendapat bagaimana memperlakukan rujukan Bacon ke doktrin Kristiani yang bertebaran dalam tulisannya. ${ }^{79}$ Karya filosofisnya mengandung tegangan yang rumit antara determinisme teologis dan kebebasan manusia. ${ }^{80}$

Intinya adalah demikian. Di satu pihak, Instauratio digambarkan sebagai penyelenggaraan ilahi yang sudah pasti akan berjalan hingga tujuan akhir tercapai. Di lain pihak, Instauratio adalah proyek yang bergantung pada upaya manusia untuk menerapkan metode, membongkar rahasia alam dan mengolah alam. Di sini, manusia bebas memilih, mau atau tidak mau menerapkan metode yang tepat itu. Artinya, manusia dalam antropologi Bacon adalah pelaku di mana kehendak dimaknai sebagai kemampuan untuk memilih. ${ }^{81}$ Tegangan ini perlu dilihat dalam bingkai sistem teologi yang dominan di Inggris semasa Bacon hidup, yang menyangkal kebebasan manusia. Bagaimanakah Bacon menyelesai-

78 Valerius, 3:218; Advancement I, 3: 267; Novum I, 4:66, Aph. LXV.

79 Pada abad XX-XXI, kajian kontemporer terhadap pemikiran Bacon dalam kaitan kelindannya dengan teologi, hukum, politik dan sastra giat berjalan sesudah Peter Beal menerbitkan Index to English Literary Manuscripts (1980) yang memuat 322 manuskrip karya Bacon. Beberapa di antaranya belum pernah diterbitkan dan bahkan sebelumnya tidak diketahui [Brian Vickers, "Francis Bacon and the Progress of Knowledge," Journal of History of Ideas, Vol. 53, No. 3 (1992), pp. 497].

80 Lih. Matthews, Science and Theology; Julian Martin, Francis Bacon, the State, and the Reform of Natural Philosophy (Cambridge: Cambridge University Press, 1992) dan Milner, "Theological Foundations".

81 Matthews, Science and Theology, pp. 39, 103-108. 
kan tegangan antara kedaulatan Allah dan kemandirian manusia tanpa membuat upaya manusia terlihat sia-sia?

\section{MENAFSIRKAN KEJATUHAN}

Antropologi teologis Bacon menempatkan Adam sebagai model bagi kemampuan manusia yang belum teraktualkan, sekaligus penjelasan bagi falibilitas epistemik serta kesengsaraannya di dunia. Sesudah Bacon, pandangan itu cukup umum di kalangan ilmuwan dan filsuf abad ke17 yang mengasalkan galat pengetahuan ke Kejatuhan. Harrison menjelaskan gejala itu, termasuk pada Bacon, dengan mencoba mengenali peluang yang ada dalam ajaran Calvin. ${ }^{82}$ Namun, analisis Harrison sebetulnya kurang mengena pada Bacon karena, seperti ditelaah oleh Matthews, pengaruh terbesar berasal dari teologi Patristik Irenaeus dari Lyons dan Lancelot Andrewes yang mengembangkan teologi Irenaeus. Hal itu mengemuka dalam A Confession of faith (1603?), traktat pendek Bacon yang memakai format pengakuan iman (credo). ${ }^{83}$

Spedding berpendapat bahwa Confession mencakup keseluruhan sistem iman yang menjadi pegangan Bacon dan bukan sekadar salinrekat dari katekismus. ${ }^{84}$ Kendati alasan Bacon menulis Confession tidak diketahui, ${ }^{85}$ traktat itu memperlihatkan pencarian akan berbagai sudut pandang teologis yang memungkinkan Bacon, mengutip Matthews, "tidak perlu lagi bergulat menyelaraskan pemikirannya dengan Calvinisme." 86 Matthews juga menemukan bahwa pemahaman teologis Bacon sejalan dengan teologi Andrewes yang dikenal sangat kritis terhadap doktrin Calvinis serta Puritan. Bacon tidak menyebut Andrewes dalam tulisannya, tetapi hubungannya dengan sosok moderat yang kerap disebut

82 Harrison, The Fall of Man, pp. 11, 16.

83 Confession diterbitkan tahun 1648, tetapi Spedding menduga naskah itu ditulis sebelum 1603. Spedding tidak dapat memastikan kapan persisnya 'sebelum' itu (Spedding, "Preface to A Confession of Faith," SEH 7: 216).

84 Spedding, "Preface to A Confession of Faith," SEH, 7: 216.

85 Vickers, Major Works, p. 561.

86 Matthews, Theology and Science, p. 41. 
sebagai Bapak teologi Anglo-Katolisisme sangat baik dan saling mempengaruhi. Andrewes ikut menyunting tulisan Bacon dan memberi masukan. ${ }^{87}$

Brian Vickers memberi dua catatan mengenai perkembangan pemahaman Bacon akan ajaran Kristiani yang tercermin dalam Confession. Di satu sisi, terlihat upaya Bacon untuk mencerna ajaran Calvin dan di sisi lain, traktat pendek itu menampung gagasan orisinal Bacon yang tidak lagi mengikuti pola baku pengakuan iman Kristiani dan kaya dengan ide pribadinya tentang alam. Dengan dua perkembangan itu Vickers berani menyimpulkan bahwa pertimbangan teologis Bacon dalam Confession diilhami oleh filsafat alamnya ${ }^{88}$ Meski tidak sampai setegas itu, Spedding juga berpendapat bahwa filsafat alam dan ide teologis Bacon membentuk kesatuan yang utuh. Skema teologi Kristiani bahkan membangun pagar bagi kemungkinan pengetahuan manusia yang sudah dibahas. ${ }^{89}$

Teologi Andrewes berpusat di ajaran inkarnasi dan theosis (pengilahian atau deifikasi) Irenaeus. ${ }^{90}$ Inkarnasi adalah pokok iman Kristiani berupa peristiwa Tuhan yang turun ke dunia dan mengambil kodrat manusia Yesus Kristus untuk keselamatan manusia. Ajaran theosis menafsirkan keselamatan tidak terbatas pada penebusan dosa manusia melalui kesengsaraan dan kematian Yesus. Kesengsaraan dan penyaliban adalah bagian sentral dan niscaya dari inkarnasi yang memungkinkan keselamatan. Kendati demikian, keselamatan juga berlangsung melalui inkarnasi yang memungkinkan penyatuan Allah dengan manusia. Inilah

87 Matthews, Theology and Science, p. 28; Spedding, LL, 3: 256; SEH, 7: 15; Bdk. Peter McCullough (ed.), "Introduction," in Lancelot Andrewes: Selected Sermons and Lectures ((Oxford: Oxford University Press, 2005), pp. xxviii, xxxiii. doi: 10.1093/actrade/ 9780198187745.book.1.

88 Vickers, Major Works, pp. xxxvi. Confession ditulis pada periode Bacon mulai menulis risalah tentang filsafat alam.

89 Spedding, "Preface," SEH, 7: 215.

90 Matthews, Science and Theology, pp. 30-31; Bdk. McCulough, "Text", in Lancelot Andrewes: pp. 140-141, 144. 
transformasi manusia hingga menyerupai Allah dan dalam persekutuan dengan Allah. Lewat inkarnasi, Allah menawarkan rahmat dan memulihkan manusia dari dalam. Secara ringkas, ajaran theosis terwakili dalam keyakinan "dengan Allah menjadi manusia, manusia menjadi Allah" seperti terungkap dalam kata-kata Irenaeus dan Athanasius. ${ }^{91}$ Dalam teologi Andrewes, misteri inkarnasi memuliakan manusia bahkan hingga ke derajat yang belum pernah ada sebelumnya, tidak pula pada Adam sebelum Kejatuhan. ${ }^{92}$

Dalam penelaahan Matthews, kesejajaran credo Bacon dengan teologi Andrewes terlihat dari penafsiran Bacon atas Kejatuhan sebagai bagian dari rencana pengilahian manusia. Di lembar pertama Bacon menyampaikan bahwa tanpa inkarnasi Allah tidak mungkin dipahami. Kejatuhan adalah peristiwa yang sudah diketahui Allah sebelum penciptaan dan Allah menjadikannya bagian dari rencana kekal untuk menyatukan kodrat manusia dengan kodrat ilahi melalui inkarnasi dan bagi karya-Nya yang tergenapi melalui Yesus. ${ }^{93}$ Akan tetapi, Kejatuhan itu sendiri bukan rencana Allah, melainkan akibat ulah manusia sendiri. Allah menyerahkan semua pertimbangan tentang yang baik dan yang jahat kepada manusia. ${ }^{94}$

Dengan demikian, selain makna soteriologis, inkarnasi juga mengandung makna antropologis. Penyatuan hipostasis Allah dengan manusia

91 Stephen Finlan and Vladimir Kharlamov (eds.), Theosis, Deification in Christian Theology (Oregon: Picwick Publications, 2006), 97-99. Sampai sekarang theosis masih merupakan motif utama yang mempersatukan berbagai aspek Gereja Timur (Ortodoks), baik aspek teologis maupun antropologis.

92 Mengutip 2 Petrus 1:4, Andrewes mengatakan bahwa manusia pada dirinya tidak dapat ambil bagian dalam kodrat ilahi. Namun, dengan kebangkitan Kristus, Roh Kudus datang dan menjadi aktif dalam diri manusia sehingga memungkinkan deifikasi [Andrewes, "Sermons of the Sending of the Holy Ghost. Preached upon Whit-Sunday Twenty-seventh of May 1610. Sermon III," Lancelot Andrewes Works, Sermons, Volume Three (Library of Anglo-Catholic Theology: Project Canterbury), pp. 145-162]. http://anglicanhistory.org/lact/andrewes/v3/whitsunday1610.html.

93 Confession, 7: 221, 223. Bdk. Matthews, Theology and Science, p. 42.

94 Confession, 7: 220. 
dalam pribadi Kristus tidak terjadi semata-mata demi penebusan dosa, tetapi bagi terciptanya "komunikasi Allah dengan ciptaan...agar terjadilah tangga sejati di dalam pribadi Pengantara yang memungkinkan Allah turun ke ciptaan dan ciptaan naik menuju Allah." ${ }^{95}$ Seperti dijelaskan Matthews, idea yang dikemukakan oleh Bacon pernah menjadi sasaran serangan Calvin kepada Andreas Osiander, ${ }^{96}$ teolog Lutheran yang dikenal sebagai penulis anonim dalam pengantar dalam buku Copernicus, De revolutionibus (1543). Menurut Calvin, Kristus adalah Pengantara karena Dia adalah Penebus dan bahwa Alkitab tidak menyebut tujuan lain dari inkarnasi. ${ }^{97}$

Dalam penelaahan Milner, apa yang mencolok dari Confession bukan pergeserannya dari ajaran Calvin (karena masih cukup banyak jejak Calvin dalam Confession), melainkan pernyataan kritis Bacon mengenai hubungan antara Kristus sebagai Pengantara dan sebagai Penebus. Bagi Milner, kutipan Wahyu 13:8, "Anak Domba yang disembelih sebelum dunia dijadikan" di paragraf kedua Confession menunjukkan bagaimana Bacon mencoba memaknai pikiran dan waktu kekal Allah. Inkarnasi adalah rencana kekal Allah. Kejatuhan di mata Allah bukan peristiwa menurut temporalitas linier manusia "sebelum" dan "sesudah," di mana Allah menetapkan Pengantara sesudah manusia jatuh ke dalam dosa. Dalam ungkapan Milner, bagi Bacon, kehadiran Kristus Pengantara bukan pikiran Allah yang datang belakangan (afterthought). Tidak pernah terjadi Allah mengkontemplasikan ciptaan secara terpisah dari peristiwa inkarnasi, kejatuhan dan penebusan..$^{98}$

95 Confession, 7: 219. Reinterpretasi Bacon atas mimpi Yakub di Betel (Kejadian 28:12) dengan pengaruh Calvin (Vickers, Major Works, pp. xl).

96 Matthews, Theology and Science, p. 42-43.

97 Matthews, Theology and Science, p. 43. Bdk. Institutio, 2.12.4. “Di mana pun Alkitab hanya mengemukakan suatu tujuan...yaitu supaya Ia menjadi kurban untuk memperdamaikan Bapa dengan kita" [Calvin, Pengajaran tentang Agama Kristen, terj. Winarsih (Jakarta: Gunung Mulia, 2008), p. 113].

98 Milner, Theological Foundations of Valerius, p. 255. Bdk. Confession, 7: 219. 
Matthews menggambarkan hubungan Allah dengan manusia dalam pernyataan iman Bacon sebagai tarian kosmik antara dua pasangan bebas. Hanya saja, pasangan yang satu mengatasi waktu dan yang lainnya terikat waktu. Allah yang berada di luar waktu sudah tahu bahwa pasangannya akan salah langkah, tetapi melanjutkan tarian sedemikian rupa sehingga kesalahan langkah itu berbalik menjadi akhir yang baik. Dengan penafsiran ini, Kristus sebagai Pengantara tidak terikat secara niscaya pada Kejatuhan. ${ }^{99}$

\section{FELIX CULPA}

Dengan penafirannya atas kedua pokok iman Kristiani tersebut, yaitu bahwa (1) Inkarnasi merupakan rencana kekal Allah dan (2) adanya kebebasan manusia yang diperhitungkan oleh Allah sejak kekekalan, Bacon dapat mempertahankan kebebasan Allah dan kebebasan manusia tanpa menimbulkan kontradiksi bagi kemahakuasaan Allah. Dalam penafsiran Vickers, langkah Bacon tersebut merupakan tanggapan terhadap kritik Gereja Katolik bagi Calvin. Karena Calvin menyangkal kebebasan manusia, Gereja Katolik mengecam Calvin menempatkan Tuhan sebagai pencipta dosa. ${ }^{100}$ Bacon mengatasi kritik itu dengan mengatakan, "aku percaya...pada mulanya Allah menciptakan segala sesuatu baik adanya" dan menjauhkan dari-Nya "awal segala kejahatan dan kesombongan" dengan menganugerahkan kebebasan kepada ciptaan. Bacon cukup berhati-hati untuk tidak mengatakan bahwa manusialah sumber kejahatan. Dosa manusia disebabkan oleh iblis yang menyelinap diam-diam ke dalam diri manusia dan mempengaruhi pilihannya. ${ }^{101}$

Berbeda dengan pola credo pada umumnya, Bacon memasukkan refleksinya tentang alam dalam hubungannya dengan Kejatuhan. Sesudah Kejatuhan, "langit dan bumi yang diciptakan untuk kebutuhan manusia ikut rusak." Padahal, hukum alam sudah ditetapkan dan "langsung bekerja begitu Allah selesai mencipta pada hari ke-6." Allah tentu

99 Matthews, Theology and Science, p. 48.

100Vickers, Major Works, p. 567. 
tidak berubah pikiran karena marah lalu mengubah seluruh hukum alam. Allah bahkan berhati-hati menjalankan mukjizat agar "tidak melanggar hukum alam" yang tidak lain adalah "ketetapan Allah sendiri atas ciptaan." Bacon lalu menafsirkan dampak Kejatuhan terhadap alam sebagai berikut, "tentang hukum Alam yang tidak berubah sampai akhir zaman ...[menjadi] urung sebagian oleh kutukan dan sejak itu tertata tanpa dapat diganggu gugat. ${ }^{102}$

Hukum alam yang urung sebagai ini dapat kita tafsirkan sebagai alam yang tidak lagi mencerminkan keagungan ciptaan seperti pada permulaan. Binatang menjadi buas, tanah tidak lagi subur, sayur mayur membusuk, sungai banjir, langit berpetir, dan sebagainya. Manusia adalah pihak yang paling merasakan dampak kutukan kepada alam, sebab sejak Kejatuhan alamlah tumpuannya memenuhi kebutuhan hidup. Kini alam memberontak kepada manusia, menolak menyingkap cara kerjanya dan menghambat usaha manusia untuk memanfaatkannya.

Sekarang kita perlu merangkum penafsiran Bacon atas Kejatuhan, baik yang tersirat maupun tersurat, dalam lingkup hubungan manusia dengan alam. Pertama, Kejatuhan memutus hubungan akalbudi dengan alam dan menceraikan laku kontemplasi dari aksi. Namun, kejatuhan tidak mengakibatkan kerusakan total dan tidak merusak akalbudi. Kedua, pengetahuan Adam adalah pengetahuan kodrati yang bertumpu ke kegiatan empiris dan diikuti laku teoretis. "Kodrati" berarti bahwa pengetahuan itu bertopang ke daya yang ada dalam diri manusia dan karena itu dapat dikembangkan untuk memulihkan hubungan manusia dengan alam. Ketiga, alam tidak rusak total tetapi sebagian hukumnya urung bekerja sesuai tujuan awal. Kutukan itu sendiri tidak dapat dibatalkan. Maka, tidak ada cara lain bagi manusia kecuali menyelidiki cara kerja alam, menafsirkan alam, mematuhi dan dari situ menemukan teknik untuk mengendalikannya. ${ }^{103}$

101Confession, 7: 222.

102Confession, 7: 221.

103 Valerius, 3: 222-223; 
Di bagian ini, dengan cerdik Bacon mengutip Kejadian 3:19 dengan menambahkan sisipan (cetak miring), "dengan kening lebih berpeluh daripada tubuhnya..." Sisipan berklausa perbandingan itu adalah cara Bacon untuk menunjukkan bahwa kuasa manusia atas alam hanya dapat dipulihkan jika dia dengan cerdas mengerahkan daya penalaran dan tidak semata-mata mengandalkan kekuatan ragawinya. ${ }^{104}$ Dari keyakinan itulah mengalir keyakinan berikut,

Oleh kejatuhan, manusia terjerembab secara serentak dari keadaan kudus dan dari kuasanya atas ciptaan. Kendati demikian, kedua hal yang hilang ini sebagian dapat dipulihkan bahkan dalam kehidupan ini. Yang pertama oleh agama dan iman, yang kedua oleh ilmu teknik dan sains. Sebab, kutukan tidak menjadikan segenap ciptaan sepenuhnya dan seterusnya membangkang. Berkat kebajikan firman "dengan wajah berpeluh engkau akan mencari rejekimu," sekarang ini, melalui bermacam-macam upaya... alam, sampai kadar tertentu, akhirnya menyerah kepada kebutuhan hidup manusia. ${ }^{105}$

Kutipan itu menutup paragraf terakhir Novum, risalah Bacon tentang cara baru menjalankan filsafat alam. Sebuah cara menafsirkan serta mematuhi alam yang pada gilirannya akan mengantar manusia kembali ke penguasaan dan kuasanya atas alam. Itulah jalan keselamatan yang sudah disediakan oleh Allah yang tidak pernah berhenti menjalankan karya Keselamatan. ${ }^{106}$ Meski demikian, tidak ada lagi yang gratis di bawah langit semenjak dosa masuk ke dunia. Keselamatan tidak datang secara automatis.

Penafsiran Bacon atas Kejatuhan menjadi sangat menarik karena dia menjadikan sanksi Allah kepada manusia (Kejadian 3: 17-19) sebagai janji bagi pemulihan material, dan bukan hanya spiritual. Bagi Bacon, di tataran materialitas dunia pun Kejatuhan-meminjam ungkapan Agustinus dalam madah Pujian Paskah—mengambil rupa felix culpa:

104 Valerius, 3: 223. Cetak miring dan penerjemahan harafiah atas kalimat Bacon. Dalam Geneva Bible, "In the sweat of thy face ...". Idem pada KJV dengan beda ejaan.

105 Novum II, 4: 248, Aph. LII. Kalimat dalam tanda petik tunggal mengacu ke Kej. 3:19. 106Confession, 7: 221. 
dosa yang menguntungkan. Dari sisi spiritual manusia beruntung menerima rahmat penebusan dan keselamatan melalui inkarnasi. Dari sisi intelektual dan material dia berpeluang menjadi manusia yang mengembangkan potensinya untuk menemukan solusi bagi persoalan dunia secara mandiri. ${ }^{107}$ Di sisi yang kedua itulah manusia hilir mudik menjelajah alam ke sana dan ke mari dan pengetahuannya bertambah.

\section{PENUTUP}

Bacon keburu meninggal sebelum menyelesaikan proyek raksasanya. Sebagai politisi kariernya berakhir tragis. Dari seorang pejabat tertinggi pengadilan dan penasihat Raja, dia dipecat dari semua jabatan dengan tuduhan menerima suap. Kehilangan tumpuan politis bagi upaya menjelmakan restorasi sains, Bacon tidak lagi yakin bahwa Instauratio akan terlaksana pada zamannya. "Aku terlalu kecil bagi hal-hal besar," demikian dia menulis. Namun, dia tidak pernah kehilangan pengharapan bahwa pada waktunya Instauratio akan berjalan sebagaimana rencana Allah. ${ }^{108}$ Tidak lama sebelum meninggal dia menulis, "kupersembahkan sesuatu yang sangat kecil ... seumpama biji sawi, pengharapan yang tertanam padanya baru akan terwujud di kemudian hari."109

Ketika pada pertengahan abad ke-17 pemikiran Bacon menuai tanggapan, baik puja puji maupun kritik, gagasan Instauratio sebagai jalan keselamatan lama kelamaan pudar dan lepas dari filsafat alamnya. Dengan bertumpu ke doktrin Kristiani, Bacon mematerialkan sejarah keselamatan dan membuka gerbang sekular bagi ide modern tentang kemajuan. Apa yang tercecer dari janji apokaliptik dalam karyanya beralih rupa menjadi visi utopis tentang sains dan teknologi. Sebuah visi tentang kemajuan di mana inti atom dapat menyelamatkan pasien kanker dan pada saat bersamaan membunuh manusia secara massal. Bacon

107Bdk. Hans Blumenberg, Work on Myth (Cambridge, Mass.: MIT Press, 1985), 350-75. 108Surat kepada Fulgentio, seorang imam Katolik yang membantu menerbitkan karya

Bacon di Italia (Letters, 7: 533).

109Experimental, 5: 127. Tentang biji sesawi lihat Mat. 13: 31-32. 
tidak merumuskan pemikiran tentang kemajuan sains, tetapi kemajuan sains yang sepenuhnya diarahkan bagi kebaikan bersama, dipandu oleh prinsip belas kasih dan dijalankan dengan rendah hati. Tanpa itu, sains hanya menghasilkan kejayaan dan kepongahan yang tidak patut dikejar, ibarat "gong yang berkumandang dan canang yang bergemerincing." 110

\section{DAFTAR RUJUKAN}

Alkitab. Jakarta: Lembaga Alkitab Indonesia, 2004.

Andrewes, Lancelot. "Sermons of the Sending of the Holy Ghost. Preached upon Whit-Sunday Twenty-seventh of May 1610. Sermon III," Lancelot Andrewes Works, Sermons, Volume Three. pp. 145-162. Library of Anglo-Catholic Theology: Project Canterbury. http:// anglicanhistory.org/lact/andrewes/v3/whitsunday1610.html. . Lancelot Andrewes: Selected Sermons and Lectures. Edited by Peter McCullough. Oxford: Oxford University Press, 2005. Oxford Scholarly Edition Online. OSEO. doi: 10.1093/actrade/ 9780198187745.book.1

Bacon, Francis. "The Masculine Birth of Time or the Great Instauration of the Dominion of Man over the Universe." In The Philosophy of Francis Bacon: An Essay on its Development from 1603 to 1609 with New Translations of Fundamental Text, ed. Benjamin Farrington, pp. 60-72. Liverpool: Liverpool University Press, 1964.

. Francis Bacon: The Major Works. Oxford World's Classics. Edited by Brian Vickers. Oxford: Oxford University Press, 2008.

. The Letters and the Life of Francis Bacon. Edited by James Spedding. In 7 volumes. London: Longman, Green, Longman and Roberts, 1861-74.

- The Oxford Francis Bacon. General editor Graham Rees. Vol. IV , IX, X, XI, XII, XIII. In 15 volumes. Oxford: Clarendon Press, 1996-... Oxford Scholarly Editions Online.

. The Works of Francis Bacon. Edited by James Spedding,

Robert Leslie Ellis and Douglas Denon Heath. In 7 volumes. London: Longman, Green, Longman and Roberts, 1859-1864. 
Bauckham, Richard. Tudor Apocalypse: Sixteenth Century Apocalypticism, Millenarianism and the English Reformation: From John Bale to John Foxe and Thomas Brightman. Oxford: The Sutton Courtenay Press, 1978.

Biblia sacra sive Testamentum Vetus (Junius, Tremellius, Bèze), 1648. https:/ / books.google.co.id/books?id=MGYOAAAAQAAJ $\&$ printsec $=$ frontcover $\& \mathrm{dq}=$ inauthor:Junius,+ Franciscus \&lr $=\&$ num $=50 \& a s \_b r r=1 \&$ redir_esc $=y \# v=$ onepage $\& \mathrm{q}=$ daniel $\& \mathrm{f}$ $=$ true

Biblia sacra Vulgata. http://www.academic-bible.com/en/onlinebibles/biblia-sacra-vulgata/read-the-bible-text/bibel/text/lesen/ stelle/27/120001/129999/ch/54203f3f95e5c34d3f62343aed $7 \mathrm{ec} 2 \mathrm{f} 1 /$

Blumenberg, Hans. Work on Myth. Cambridge, MA: MIT Press, 1985.

Calvin, John. Pengajaran tentang Agama Kristen. Diterjemahkan oleh Winarsih. Jakarta: Gunung Mulia, 2008

Clouse, Robert G. “John Napier and Apocalyptic Thought." The Sixteenth Century Journal, Vol. 5, No. 1 (Apr., 1974): 101-114.

Doelman, James. King James I and the Religious Culture of England. Cambridge: D.S. Brewer, 2000.

Donne, John. Meditation XIX. http://www.luminarium.org/sevenlit/ donne/meditation19.htm

Donnelly, John Patrick. "Jesuit's Writings of the Early Modern Period, 1540-1640. Indianapolis: Hackett Publishing, 2006.

Fagin, Dan. A Story of Science and Salvation. New York: Bantam Books, 2013.

Feingold, Mordechai and Victor Navarro-Brotons. Universities and Science in the Early Modern Period. Dordrecht: Springer, 2006.

Finlan, Stephen and Vladimir Kharlamov (editors). Theosis, Deification in Christian Theology. Oregon: Picwick Publications, 2006.

Gascoigne, John. "The Religious Thought of Francis Bacon." In Religion and Retributive Logic. Essays in Honour of Professor Garry W. Trompf, eds. Carole M. Cusack and Christopher Hartney, pp. 209-228. Leiden: Brill, 2010.

Hanson, Paul. "What is Apocalyitic Literature." In The Oxford Handbook of Apocalyptic Literature, ed. John J. Collins, p. 1-16. Oxford: Oxford University Press, 2014 
Harrison, Peter. "Curiosity, Forbidden Knowledge, and the Reformation of Natural Philosophy in Early Modern England." Isis, Vol. 92 (2001): 265-290.

. "Original Sin and the Problem of Knowledge in Journal of the History of Ideas. Early Modern Europe." Vol. 63, No. 2 (Apr., 2002): 239-259.

. The Fall of Man and the Foundations of Modern Science. Cambridge: Cambridge University Press, 2007.

Hill, Christopher. Intellectual Origins of the English Revolution-Revisited. Oxford: Clarendon Press, 1997

Hoekema, Anthony A. Manusia: Ciptaan menurut Gambar Allah. Diterjemahkan oleh Irwan Tjulianto, disunting oleh Hendry Ongkowidjojo. Surabaya: Penerbit Momentum, 2012.

Holocaust Encyclopedia, http://www.ushmm.org/wlc/en/article.php? ModuleId=10007062.

Kamus Besar Bahasa Indonesia, edisi ke-3. Jakarta: Badang Pengembangan dan Pembinaan Bahasa, 2005.

Laërtius, Diogenes. Lives of the Eminent Philosophers, Vol. I in two volumes, translated by Robert Drew Hicks. Cambridge, MA: Harvard University Press, 1959

Longman, Tremper. The Book of Ecclesiastes, New International Commentary on the Old Testament. Grand Rapids: Eerdmans, 1998.

Martin, Julian. Francis Bacon, the State, and the Reform of Natural Philosophy. Cambridge: Cambridge University Press, 1992.

Martinich, Aloysius P. Hobbes: A Biography. Cambridge: Cambridge University Press, 1999.

Matthews, Steven. Theology and Science in the Thought of Francis Bacon. Hampshire: Ashgate Publishing Limited, 2008.

Maynard, Katharine. "Science in Early English Literature 1550 to 1650." Isis, Vol. 17, No. 1 (1932): 94-126.

McGrath, Alister. Reformation Thought: An Introduction. Oxford: WilleyBlackwell, 2012.

McKnight, Stephen A. The Religious Foundations of Francis Bacon. London: University of Missouri Press, 2006.

Merton, Robert K. "Science, Technology and Society in Seventeenth Century England." Osiris, Vol. 4 (1938): 360-632. 
Midgley, Mary. Science as Salvation: A modern Myth and its Meaning. London: Routledge, 1992.

Milner, Benjamin. "Francis Bacon: the Theological Foundations of 'Valerius Terminus,'" Journal of the History of Ideas, Vol. 58, No. 2 (April 1997): 245-264.

Milton, Anthony. Catholic and Reformed: The Roman and Protestant Churches in English Protestant Thought, 1600-1640. Cambridge: University of Cambridge, 1995.

Napel, Henk ten. Kamus Teologi Inggris Indonesia. Jakarta: BPK Gunung Mulia, 2005.

Paganini, Gianni and José R. Maia Neto. Editors. Renaissance Scepticisms. Dordrecht: Springer, 2009.

Peltonen, Markku. The Cambridge Companion to Bacon. Cambridge: Cambridge University Press, 1996.

Pool, Jeff B. God's Wounds: Hermeneutic of the Christian Symbol of the Divine Suffering, Vol. 2. Eugene: Wipf \& Stock, 2010.

Spellman, William H. Locke and the Problem of Depravity. Oxford: Oxford University Press, 1988.

The Bible and Holy Scriptures (The Geneva Bible), 1560. https:// www.originalbibles.com/the-geneva-bible-1560/

The Holy Bible, King James Version, 1611. http://www.kingjamesbible online.org/1611-Bible/

Verkamp, Bernard J. The Indifferent Mean: Adiaphorism in the English Reformation to 1554. Athens, OH: Ohio University Press, 1977.

Vickers, Brian. "Francis Bacon and the Progress of Knowledge." Journal of History of Ideas, Vol. 53, No. 3 (1992): 495-518.

Waterworth, James (translator \& editor). The Council of Trent: The canons and decrees of the sacred and oecumenical Council of Trent. London: Dolman, 1848.

Webster, Charles. The Great Instauration: Science, Medicine, and Reform, 1626-1660. New York: Holmes and Meier Publishers, 1976.

Whitney, Charles. "Francis Bacon's Instauratio: Dominion of, and over, Humanity." Journal of the History of Ideas, Vol. 50 No. 3 (July September 1989): 371-390.

Zagorin, Perez. Francis Bacon. Princeton: Princeton University Press, 1998. 